OPEN ACCESS

Edited by:

Alberto Bosque,

George Washington University,

United States

Reviewed by:

Scott Kitchen,

University of California, Los Angeles,

United States

Sofia A. Casares,

Naval Medical Research Center,

United States

*Correspondence:

Justin Pollara

justin.pollara@duke.edu

Specialty section:

This article was submitted to

Vaccines and Molecular Therapeutics,

a section of the journal

Frontiers in Immunology

Received: 08 January 2020

Accepted: 30 March 2020

Published: 21 April 2020

Citation:

Pollara J, Edwards RW, Jha S,

Lam C-YK, Liu L, Diedrich G,

Nordstrom JL, Huffman T, Pickeral JA, Denny TN, Permar SR and Ferrari G

(2020) Redirection of Cord Blood T

Cells and Natural Killer Cells for

Elimination of Autologous

HIV-1-Infected Target Cells Using

Bispecific DART ${ }^{\circledR}$ Molecules.

Front. Immunol. 11:713.

doi: 10.3389/fimmu.2020.00713

\section{Redirection of Cord Blood T Cells and Natural Killer Cells for Elimination of Autologous HIV-1-Infected Target Cells Using Bispecific DART ${ }^{\circledR}$ Molecules}

\author{
Justin Pollara ${ }^{1,2 *}$, R. Whitney Edwards ${ }^{2}$, Shalini Jha ${ }^{1,2}$, Chia-Ying Kao Lam ${ }^{3}$, Liqin Liu ${ }^{3}$, \\ Gundo Diedrich ${ }^{3}$, Jeffrey L. Nordstrom ${ }^{3}$, Tori Huffman ${ }^{1}$, Joy A. Pickeral ${ }^{1}$, \\ Thomas N. Denny ${ }^{2}$, Sallie R. Permar ${ }^{2,4}$ and Guido Ferrari ${ }^{1,2}$
}

\footnotetext{
'Department of Surgery, Duke University School of Medicine, Durham, NC, United States, ${ }^{2}$ Human Vaccine Institute, Duke University School of Medicine, Durham, NC, United States, ${ }^{3}$ Macrogenics, Inc., Rockville, MD, United States, ${ }^{4}$ Department of Pediatrics, Duke University School of Medicine, Durham, NC, United States
}

Mother-to-child transmission of HIV-1 remains a major global health challenge. Currently, HIV-1-infected infants require strict lifelong adherence to antiretroviral therapy to prevent replication of virus from reservoirs of infected cells, and to halt progression of disease. There is a critical need for immune interventions that can be deployed shortly after infection to eliminate HIV-1-infected cells in order to promote long-term remission of viremia, or to potentially cure pediatric HIV-1-infection. Bispecific HIV $\times$ CD3 DART ${ }^{\circledR}$ molecules able to co-engage the HIV-1 envelope protein on the surface of infected cells and CD3 on cytolytic T cells have been previously shown to eliminate HIV-1 infected cells in vitro and are candidates for passive immunotherapy to reduce the virus reservoir. However, their potential utility as therapy for infant HIV-1 infection is unclear as the ability of these novel antibody-based molecules to work in concert with cells of the infant immune system had not been assessed. Here, we use human umbilical cord blood as a model of the naivve neonatal immune system to evaluate the ability of HIV x CD3 DART molecules to recruit and redirect neonatal effector cells for elimination of autologous CD4+ T cells infected with HIV-1 encoding an envelope gene sequenced from a motherto-child transmission event. We found that HIV $\times$ CD3 DART molecules can redirect $\mathrm{T}$ cells present in cord blood for elimination of HIV-infected CD4 ${ }^{+} \mathrm{T}$ cells. However, we observed reduced killing by $T$ cells isolated from cord blood when compared to cells isolated from adult peripheral blood-likely due to the absence of the memory and effector $\mathrm{CD}^{+} \mathrm{T}$ cells that are most cytolytic when redirected by bispecific DART molecules. We also found that newly developed HIV $\times$ CD16 DART molecules were able to recruit CD16-expressing natural killer cells from cord blood to eliminate HIV-infected cells, and the activity of cord blood natural killer cells could be substantially increased 
by priming with IL-15. Our results support continued development of HIV-specific DART molecules using relevant preclinical animal models to optimize strategies for effective use of this immune therapy to reduce HIV-1 infection in pediatric populations.

Keywords: pediatric HIV-1, umbilical cord blood, cytotoxic T cells, natural killer cells, redirected cytotoxicity, bispecific DART molecules

\section{INTRODUCTION}

Despite the effectiveness of perinatal and postnatal antiretroviral prophylaxis, and the relatively low transmission rates of HIV1 in utero, intrapartum, and during breast-feeding, there remain over 160,000 new pediatric HIV-1 infections annually worldwide (1-4). The overwhelming majority of these infections occur perinatally, via mother-to-child transmission. Treatment is critical as infant HIV-1 peak and set-point viral loads are typically 10 -fold above those observed for primary adult infection and are highly predictive of disease outcome (5-12). With proper adherence, antiretroviral therapy (ART) can successfully control viremia in infants, and if initiated shortly after birth, ART may appreciably limit the size of the latently infected cell reservoir $(13,14)$. However, evidence to date suggests that strict adherence to ART will need to be maintained lifelong to prevent reemergence of virus replication resulting from reactivation of latent infection. Therefore, to provide long-term control or cure of pediatric HIV infection and abrogate the need for lifelong viral suppression, early initiation of ART will need to be combined with additional strategies to eliminate HIV-1-infected cells responsible for persistence of the virus reservoir.

One promising approach to increase elimination of HIV-infected cells is passive immunotherapy with antibodybased molecules capable of recruiting and redirecting endogenous cytolytic effector cells $(15,16)$. Bispecific HIV $\times$ CD3 DART $^{\circledR}$ molecules based on HIV-specific monoclonal antibodies (mAbs) can effectively mediate in vitro elimination of HIV-1 infected and reactivated latently infected cells $(17,18)$. Bispecific HIV $\times$ CD3 DART molecules use a monovalent HIVtargeting arm comprised of the antigen-binding region of $\mathrm{mAbs}$ specific for highly conserved regions of the HIV envelope protein (Env) to recognize HIV-1-infected target cells, and a monovalent CD3 binding arm for recruitment of cytolytic T cells. Only when both arms are co-engaged will polyclonal $\mathrm{T}$ cells be activated and redirected for cytolytic responses against Env-expressing, HIV-1-infected target cells in a major histocompatibility complex-independent manner $(18,19)$. As a result of these properties, HIV $\times$ CD3 DART molecule-mediated activity should be unaffected by mutations among circulating or latent viruses that confer escape from viral-specific T-cell responses, or by the low frequency and functionality of HIV-specific T cells in patients on ART $(20,21)$. Therefore, passive immunization with $\mathrm{HIV} \times \mathrm{CD} 3$ DART molecules could form the basis of a strategy for cure of HIV by combining early initiation of ART to control viral load and reduce the size of the reservoir with concurrent initiation of HIV $\times$ CD3 DART molecule immunotherapy to eliminate infected cells. Once viral load is below detection, ART and DART molecule immunotherapy would be maintained with the addition of compounds that reactivate latent virus-infected cells to generate targets for DART molecule-mediated clearance.

Newborn infant infection resulting from mother-to-child transmission of HIV-1 (MTCT) likely represents the most favorable clinical context for successful passive immunotherapy to eliminate the reservoir of HIV-infected cells. Therapy can be initiated shortly after birth, and therefore near the time of transmission events occurring late in utero, during labor and delivery, or via breast milk - likely prior to the establishment of large populations of latently infected cells and the onset of immune dysregulation (22-25). However, neonatal cytolytic immune cells have phenotypic and functional differences compared to the same cell populations in adults $(26,27)$, and the impact of these differences on the activity of cytotoxic antibody-based immunotherapeutic drugs is not known. Thus, it is crucial to first evaluate infant passive immunotherapies in a model system that recapitulates the effector cells present in newborn infants.

In this study, we used human umbilical cord blood as surrogate for neonatal peripheral blood to test the hypothesis that bispecific DART molecules could redirect neonatal effector cells for elimination of cells infected with HIV-1 encoding an envelope gene sequenced from a mother-to-child transmission event. Our data demonstrate that HIV $\times$ CD3 DART molecules can redirect cord blood $\mathrm{T}$ cells to kill autologous cord blood $\mathrm{CD}^{+}{ }^{+} \mathrm{T}$ cells infected by HIV-1 in vitro. However, we observed reduced killing by $\mathrm{T}$ cells isolated from cord blood when compared to those isolated from adult peripheral blood. We also found that HIV $\times$ CD16 DART molecules can recruit and redirect natural killer (NK) cells from cord blood to eliminate autologous HIV-infected $\mathrm{CD}^{+}{ }^{+} \mathrm{T}$ cells; and we determined that the redirected activity of cord blood NK cells can be substantially increased by priming with IL-15. Our data suggest that HIV-specific DART molecules combined with current ART regimens may provide a novel treatment option intended to improve virus control, promote long-term remission, or cure pediatric HIV-1 infection. Our data also indicate that strategies to optimize and enhance the cytotoxic potential of neonatal effector cells, or allowing additional time after birth for the immune system to develop, will likely be needed to maximize the therapeutic potential of HIV-specific DART molecules for use in pediatric populations.

\section{MATERIALS AND METHODS}

\section{Study Samples}

\section{Blood and Mononuclear Cell Samples}

Anonymized human umbilical cord blood donations that failed to meet the volume and/or nucleated cell count criteria required for clinical use were obtained with informed written 
consent. Human peripheral venous blood was collected by leukapheresis from healthy consenting adult volunteers $(28,29)$. All samples were collected in accordance with the policies and regulations of the Duke Health Institutional Review Board. Cord blood mononuclear cells (CBMC) and adult peripheral blood mononuclear cells (PBMC) were processed from umbilical cord blood and human peripheral blood, respectively, using density gradient centrifugation with Ficoll-Paque plus (GE Healthcare Life Sciences, Pittsburg, PA), and were cryopreserved in $10 \%$ DMSO 90\% Fetal Bovine Serum (FBS). All samples were processed within $12 \mathrm{~h}$ after collection.

\section{Bispecific HIV x CD3 and HIV x CD16 DART Molecules}

HIV $\times$ CD3 DART molecules were constructed with anti-HIV1 envelope specificities based on non-neutralizing mAbs, 7B2 or A32, or an irrelevant control specificity based on the antirespiratory syncytial virus (RSV) mAb, palivizumab, and with an anti-human CD3E specificity based on the mAb, hXR32, as described previously $(18,30)$. These molecules are referred to as $7 \mathrm{~B} 2 \times \mathrm{CD} 3, \mathrm{~A} 32 \times \mathrm{CD} 3$, and RSV $\times \mathrm{CD} 3 . \mathrm{HIV} \times \mathrm{CD} 16 \mathrm{DART}$ molecules were constructed with anti-human CD16 specificities based on mAb h3G8 as the effector arm, which included 7B2 $\times \mathrm{CD} 16$ and $4420 \times \mathrm{CD} 16$, where 4420 is an anti-fluorescein (control) specificity, and Fc-bearing ones based on mAb h5H2 as the effector arm included 7B2 $\times$ CD16, A32 $\times$ CD16, and RSV $\times$ CD16. The human immunoglobulin G1 (IgG1) Fc domain, which is incorporated to prolong circulating half-life in vivo, contains mutations to greatly reduce or eliminate effector function via binding to Fc-gamma receptors (Fc $\gamma$ Rs) and complement, while retaining binding to the neonatal $\mathrm{Fc}$ receptor $(\mathrm{FcRn})$ to take advantage of the IgG salvage pathway mediated by this receptor.

\section{Laboratory Methods \\ Phenotypic Characterization of T Cells}

Immunophenotyping of human $\mathrm{T}$ cells was performed using flow cytometry analyses. Cryopreserved PBMC (5 donors) and CBMC (14 donors) were thawed and incubated overnight (18 h) in RPMI 1640 medium supplemented with $10 \% \mathrm{FBS}$ at $37^{\circ} \mathrm{C}$, $5 \% \mathrm{CO}_{2}$. The cells were then washed with buffered saline and stained with a viability marker (Fixable Aqua Dead Cell Stain Kit, Thermo Fisher Scientific, San Diego, CA) prior to surface and intracellular staining with fluorescently conjugated antibodies using standard techniques as described (31). The staining panel used to identify $\mathrm{T}$ cell subsets and phenotypes was based on the Optimized Multicolor Immunofluorescence Panel 22 (OMIP-22) described previously (31). Fluorescently conjugated Abs used for cell surface staining were: APCeFluor780-CD4 (clone RPA-T4, ebioscience, San Diego, CA); Horizon V500-CD14 (clone M5E2, BD Biosciences, San Jose, CA); Horizon V500-CD19 (clone HIB19, BD Biosciences); BV785-CD45RO (clone UCHL1, Biolegend, San Diego, CA); BV605-CCR7 (clone G043H7, Biolegend); and APC-CD366 (clone F38-2E2, Biolegend). Intracellular staining was performed with PE-TR-CD3 (clone UCHT1, Beckman Coulter, Brea, CA); and Ax700-CD8 (clone HIT8a, Biolegend). Data analyses were performed using FlowJo software (v10.5.3) from BD Biosciences.

\section{Phenotypic Characterization of NK Cells and CD16 DART-Molecule NK Cell Binding}

Immunophenotyping of human NK cells was performed as previously described (32). Cryopreserved PBMC collected from 15 healthy normal adult donors, and CBMC from 15 umbilical cord blood donors, were thawed and incubated overnight $(18 \mathrm{~h})$ in RPMI1640 medium supplemented with $10 \%$ FBS, or in RPMI 1640 medium supplemented with 10\% FBS and $10 \mathrm{ng} / \mathrm{mL}$ recombinant human IL-15 (Miltenyi Biotec, $\mathrm{GmbH})$ at $37^{\circ} \mathrm{C}, 5 \% \mathrm{CO}_{2}$. The cells were then washed with buffered saline and stained with a viability marker (Fixable Aqua Dead Cell Stain Kit, Thermo Fisher Scientific) prior to surface and intracellular staining with fluorescently conjugated Abs using standard techniques as described previously (33). Fluorescently conjugated antibodies used for surface staining were based on OMIP-007 and are as follows: PE-TR-CD3 (clone S4.1, Thermo Fisher Scientific); APC-H7-CD4 (clone SK3, BD Biosciences); PE-Cy5-CD14 (clone Tuk4, Thermo Fisher Scientific); PE-Cy5-CD19 (clone SJ25-C1, Thermo Fisher Scientific); PacificBlue-CD16 (clone 3G8, BD Biosciences); PECy7-CD56 (clone NCAM16.2, BD Biosciences); BV606-CD62L (clone DREG-56, Biolegend); FITC-HLA-DR (clone G46-6, BD Biosciences); APC-CD57 (clone HCD57, Biolegend); and BV785-CD69 (clone FN50, Biolegend). Intracellular staining was performed with BV711-Perforin (clone dG9, Biolegend), and PEGranzyme B (clone GB11, BD Biosciences). Quantum ${ }^{\mathrm{TM}}$ Simply Cellular ${ }^{\circledR}$ beads (Bangs Laboratories, Inc., Fishers, Indiana) were used to determine the antibody binding capacity $(A B C)$ of perforin and granzyme within cells according the manufacturers recommended procedure. Data analyses were performed using FlowJo software (v10.5.3).

To determine if DART molecules with CD16 targeting arms could specifically bind the surface of human NK cells, we incubated purified human NK cells with DART molecules at $1 \mu \mathrm{g} / \mathrm{ml}$ for $40 \mathrm{~min}$ at room temperature. Cells were then washed (PBS with $1 \%$ FBS) and incubated with $1 \mu \mathrm{g} / \mathrm{ml}$ mouse antiEK antibody (recognizes the $\mathrm{E} / \mathrm{K}$ heterodimerization region of DART molecules, MacroGenics) for $20 \mathrm{~min}$ at $4^{\circ} \mathrm{C}$ in wash buffer. Cells were then washed and incubated with PE rat-anti mouse IgG1 (BD Biosciences), at the manufactures recommended concentration, in wash buffer, for $25 \mathrm{~min}$ at $4^{\circ} \mathrm{C}$. Finally, cells were washed, fixed, and analyzed by flow cytometry. Data are reported as mean fluorescent intensity (MFI) of PE.

\section{Redirected T Cell Cytotoxicity Assay Against Autologous HIV-1 Env-Expressing CD4 ${ }^{+}$T Cells}

Redirected $\mathrm{T}$ cell cytotoxicity assays were performed with methods similar to those previously described (18). Cryopreserved resting CBMC and PBMC from normal healthy donors were activated for $72 \mathrm{~h}$ with anti-human CD3 antibody (clone OKT3, eBioscience), anti-human CD28 antibody (clone 28.2, BD Biosciences) each at $150 \mathrm{ng} / \mathrm{mL}$, and recombinant human IL-2 (30 U/mL, Proleukin, Prometheus Therapeutics and Diagnostics) in RPMI 1640 media supplemented with 20\% FBS. Next, CD $8^{+} \mathrm{T}$ cells were depleted using magnetic beads (Miltenyi Biotec), leaving a $\mathrm{CD}^{+} \mathrm{T}$ cell-enriched population that was then infected with HIV-1 infectious molecular clone virus 
(HIV-1 4403bmC5) encoding a subtype C infant postnatallytransmitted/founder envelope protein (34) and Tat-inducible Renilla luciferase reporter gene (35), by spinoculation as described (36). Where indicated, cells were alternatively infected with an infectious molecular clone virus representing HIV-1 subtype B isolate BaL. After $48 \mathrm{~h}$ of infection, the $\mathrm{CD} 4^{+} \mathrm{T}$ cells were incubated with $\mathrm{CD}^{+} \mathrm{T}$ cells purified from autologous PBMC or CBMC using negative selection with magnetic beads (human $\mathrm{CD}^{+} \mathrm{T}$ cell isolation kit, Miltenyi Biotec) at a $\mathrm{CD} 8^{+}$ $\mathrm{T}$ cell to target cell ratio of $30: 1$ in $1 / 2$ area opaque flat bottom plates (Corning Life Sciences, Corning, NY). HIV $\times$ CD3 DART molecules were added, in duplicate, using 10-fold serial dilutions starting at $1 \mu \mathrm{g} / \mathrm{mL}$, and the plates were incubated for an additional $24 \mathrm{~h}$ at $37^{\circ} \mathrm{C}, 5 \% \mathrm{CO}_{2}$. Control plates included only infected $\mathrm{CD}^{+}{ }^{+}$target cells and DART molecules without autologous $\mathrm{CD}^{+} \mathrm{T}$ effector cells. Percent of specific killing was calculated based on the change in Relative Light Units (RLU) (ViviRen luciferase assay; Promega, Fithchburg, WI) resulting from the loss of live, intact target cells in test wells containing effector cells, target cells, and DART molecules relative to RLU in control wells containing target cells and effector cells alone (without DART molecules) according to the following formula: percent of specific killing $=[$ (number of RLU of control well - number of RLU of test well)/number of RLU of control well] $\times 100$. Positive responses were defined as specific killing $>20 \%$. Data were fit to a sigmoidal dose-response function for graphing and for determination of $50 \%$ effective concentrations $\left(\mathrm{EC}_{50}\right)$. In most cases, data are reported as positive area under the curve (pAUC), defined as the area under the log-transformed dilution curve that is above the threshold for positivity $(20 \%$ specific killing), calculated with the trapezoidal method using SAS software (SAS Institute Inc., Cary, NC).

\section{In vitro Evaluation of Strategies to Improve Redirected T Cell Cytotoxicity}

Exogenous cytokines and T-cell co-stimulators were incorporated into the redirected $\mathrm{T}$ cell cytotoxicity assay to test their ability to improve the cytolytic activity of $\mathrm{T}$ cells present in CBMC and PBMC. The impact of exogenous IL-12 was evaluated by overnight incubation of the CBMC and PBMC with exogenous recombinant human IL-12 (10 ng/mL, Miltenyi Biotec), before isolation of $\mathrm{CD}^{+}{ }^{+} \mathrm{T}$ cells used as effector cells in the redirected cytotoxicity assay. IL-12 was maintained in the assay plates at $10 \mathrm{ng} / \mathrm{mL}$ throughout the 24 -h killing assay. The impact of coreceptor signaling was assessed by incubating the CBMC and PBMC overnight with anti-CD28 (150 ng/mL, clone 28.2, BD Biosciences) or anti-CD137 (150 ng/mL, clone 4B4-1, BioLegend), prior to isolation of $\mathrm{CD}^{+} \mathrm{T}$ cells, and maintaining the presence of the anti-coreceptor antibodies throughout the killing assay. Experiments were also performed using exogenous IL-12, anti-CD28, and anti-CD137 together, or with cells stimulated for $48 \mathrm{~h}$ by incubation with $150 \mathrm{ng} / \mathrm{mL}$ anti-human CD3 antibody (clone OKT3, eBioscience), anti-human CD28 antibody, and $30 \mathrm{U} / \mathrm{mL}$ recombinant human IL-2 in RPMI 1640 media supplemented with $20 \%$ FBS prior to isolation of $\mathrm{CD}^{+}$ $\mathrm{T}$ cells. In one set of experiments, T cells in CBMC and PBMC were activated for $72 \mathrm{~h}$ with anti-CD3, anti-CD28, and IL-2, before isolation of $\mathrm{CD}^{+} \mathrm{T}$ cells, which were then allowed to rest for $72 \mathrm{~h}$ in absence of any stimulation before use as effector cells according to the methods described above.

\section{Redirected NK Cell Cytotoxicity Assay Against Autologous HIV-1 Env-Expressing CD4 ${ }^{+}$T Cells}

Cryopreserved CBMC and PBMC samples were thawed and rested overnight $(18 \mathrm{~h})$ at $37^{\circ} \mathrm{C} 5 \% \mathrm{CO}_{2}$ in $\mathrm{RPMI} 1640$ media supplemented with $10 \%$ FBS, or media supplemented with $10 \mathrm{ng} / \mathrm{mL}$ recombinant human IL-15 (Miltenyi Biotec), as previously described (32). Subsequently, NK cells were purified by negative selection with magnetic beads (human NK cell isolation kit, Miltenyi Biotec) and used as effector cells (NK cell to target cell ratio of 5:1) in redirected cytotoxicity assays using HIV $\times$ CD16 DART molecules, performed as described above. Positive responses were defined as specific killing $>20 \%$, and data were not fit to a dose-response function for graphing due to the presence of a prozone (37).

\section{CD107a Degranulation Assay}

Cell-surface expression of CD107a was used as a marker for $\mathrm{T}$ cell degranulation (38). Redirected cytotoxicity assays were performed as described above, with the following modification [as previously described in (18)]. After plating the target cells, effector cells, and DART molecules, the plate was incubated for $18 \mathrm{~h}$ and then FITC- or APC-Cy7-CD107a antibody (clone H4A3, BD Biosciences), brefeldin A (GolgiPlug, $1 \mu \mathrm{L} / \mathrm{mL}$, $\mathrm{BD}$ Biosciences), and monensin (GolgiStop, $4 \mu \mathrm{L} / 6 \mathrm{~mL}, \mathrm{BD}$ Biosciences) were added to each well and the plates were incubated for an additional $6 \mathrm{~h}$. Plates were then washed and stained with a viability marker and fluorescently conjugated antibodies as described above (phenotypic characterization of $\mathrm{T}$ cells), or with a truncated staining panel that included only antibodies specific for CD3, CD4, and CD8, using standard techniques. Data analyses were performed using FlowJo software (v10.5.3).

\section{Statistical Methods}

Kruskal Wallis tests were used to compare response magnitudes across groups. In order to assess if two groups have different response magnitudes, pairwise comparisons between groups were conducted using Wilcoxon rank sum test. Two-tailed $p<0.05$ were considered significant. Statistical analysis was performed using SAS software (SAS Institute Inc.).

\section{RESULTS}

\section{Cord Blood T Cells Have Modest Ability to Eliminate Autologous HIV-Infected CD4 T Cells Directed by HIV x CD3 DART Molecules in vitro}

We and others have demonstrated that bispecific DART molecules able to co-engage HIV-1 Env on infected cells, and CD3 antigen on cytolytic T cells, can be used to eradicate acutely infected and reactivated latently-infected cells in vitro $(17,18)$. However, these initial studies were performed using immune cells from adults - the ability of these novel antibody-based molecules 
to work in concert with cells present in the neonatal immune system cells had not been explored. To address this limitation, we performed redirected $\mathrm{T}$ cell cytotoxicity assays using CBMC as a source of neonatal $\mathrm{CD}^{+}{ }^{+} \mathrm{T}$ cells for use as effectors, and autologous cord blood $\mathrm{CD}^{+}{ }^{+} \mathrm{T}$ cells for use as targets after infection with HIV-1 in vitro. Target cells were infected with a subtype C HIV-1 infectious molecular clone virus that encodes the env gene from HIV-1 4403bmC5, a postnatally-transmitted founder virus isolated from infant plasma, and identical to a virus isolate present in matched maternal breast milk (34). Thus, this isolate is expected to be a representative of those present in the early active and latent virus reservoirs of infected infants. Assays were also performed using adult PBMC as a source of effector cells and autologous HIV-1 4403bmC5-infected target cells for comparison. We observed minimal background activity (specific killing $<20 \%$ ) by the negative control DART molecule, RSV $\times$ $\mathrm{CD} 3$, in assays performed with $\mathrm{CD}^{+} \mathrm{T}$ cells and autologous 4403bmC5-infected $\mathrm{CD}^{+}{ }^{+}$cells isolated from adult PBMC (black lines and open squares, Figure 1A) or CBMC (blue lines and circles, Figure 1A). In contrast, HIV-specific DART molecules, $7 \mathrm{~B} 2 \times \mathrm{CD} 3$ and $\mathrm{A} 32 \times \mathrm{CD} 3$, mediated specific killing activity with cells isolated from most donors ( $80 \%$ of CBMC samples, and $89 \%$ of PBMC samples with $7 \mathrm{~B} 2 \times \mathrm{CD} 3 ; 17 \%$ of CBMC and $100 \%$ of PBMC samples with A32 $\times \mathrm{CD} 3$ ) as shown in Figures 1B,C, respectively. However, we observed that the specific killing activity of cells from cord blood is reduced when compared to those from adult PBMC for the majority of samples, both in terms of maximum observed killing activity (Figures 1B,C), and $\mathrm{EC}_{50}$ (mean $\sim 100 \mathrm{ng} / \mathrm{mL}$ for $7 \mathrm{~B} 2 \times \mathrm{CD} 3$ with CBMC samples that were positive for killing, and $\sim 4 \mathrm{ng} / \mathrm{mL}$ with positive PBMC samples). To better compare the killing activities, we calculated the positive area under the dilution curves (Figure 1D), and confirmed that specific killing of HIV-1 4403bmC5-infected cells was significantly lower in assays performed with cells isolated from CBMC compared to adult PBMC ( $p \leq 0.001$, Wilcoxon rank sum tests). These data demonstrate that HIV-specific DART molecules can redirect cord blood T cells to kill HIV-1 infected, Env-expressing, autologous cord blood $\mathrm{CD} 4^{+} \mathrm{T}$ cells, however with activity subordinate to that mediated by adult peripheral blood T cells. Therefore, we next sought to identify characteristics of cord blood $\mathrm{T}$ cells that may limit their functionality when redirected by HIV-specific DART molecules.

\section{Comparison of Effector and Memory T Cell Subsets in Cord Blood and Adult Peripheral Blood}

We used flow cytometry immunophenotyping to compare $\mathrm{T}$ cell subsets present in CBMC to those present in adult PBMC. Comparisons were made using cells isolated from 14 cord blood and 5 adult peripheral blood samples. The gating strategy used to identify total $\mathrm{T}$ cells, and $\mathrm{T}$ cell subsets - naïve, effector, effector memory $\left(\mathrm{T}_{\mathrm{EM}}\right)$, and central memory $\left(\mathrm{T}_{\mathrm{CM}}\right)-$ is indicated in Figure 2A. Flow plots showing representative examples of $\mathrm{CD}^{+}$and $\mathrm{CD}^{+} \mathrm{T}$ cell subsets among PBMC and CBMC are shown in Figures 2B,C, respectively. Consistent with prior observations $(39,40)$, we found that although CBMC contained
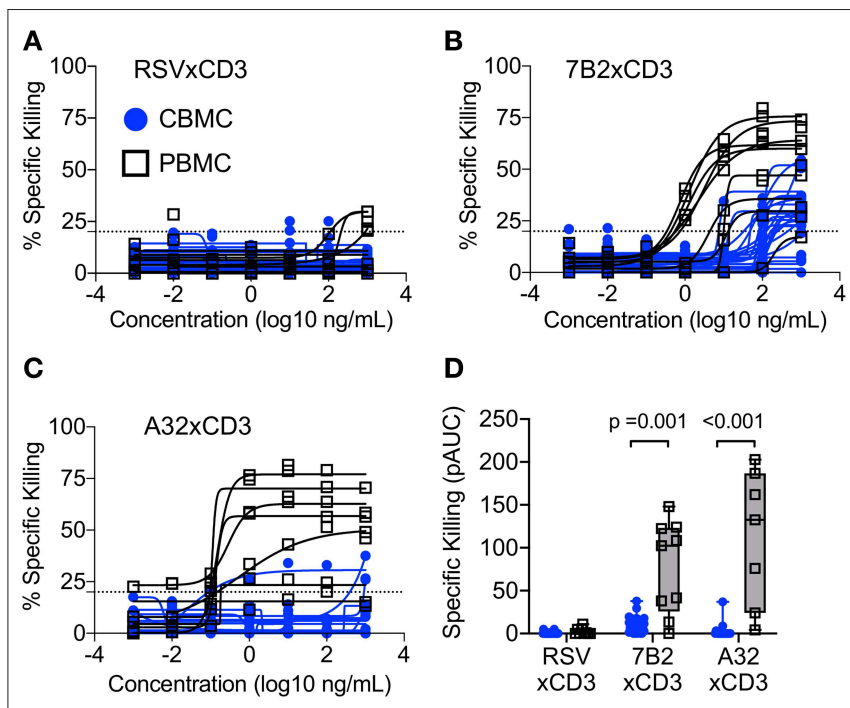

FIGURE 1 | Redirection of cytolytic T cells to autologous HIV-infected CD4 ${ }^{+} \mathrm{T}$ cells by HIV $\times$ CD3 DART molecules. The ability of T cells isolated from cord blood mononuclear cells (CBMC, blue lines, and symbols) and adult peripheral blood mononuclear cells (PBMC, black lines, and open symbols) to eliminate autologous $\mathrm{CD}^{+}{ }^{+} \mathrm{T}$ cells infected with an HIV-1 molecular clone virus representing an infant postnatally-transmitted founder isolate (HIV-1 4403bmC5) after being redirected by (A) RSV $\times$ CD3 control DART molecules ( $n=25$ CBMC samples, $n=9$ PBMC samples), (B) 7B2 $\times$ CD3 DART molecules ( $n=25$ CBMC samples, $n=9$ PBMC samples), and (C) A32 $\times$ CD3 DART molecules ( $n=18$ CBMC samples, $n=7$ PBMC samples).

Dashed line indicates the threshold for positivity. The positive areas under the dilution curves (pAUC) are presented in (D) with blue circles and bars representing assays performed with cells from CBMC and black/gray squares and bars representing assays performed with cells from adult PBMC. Box plots represent the interquartile ranges, horizontal lines indicate the medians, and error bars extend to the minimum and maximum observed values. Data are from $24 \mathrm{~h}$ killing assays with a $\mathrm{CD}^{+}$effector to HIV-infected autologous $\mathrm{CD}^{+}{ }^{+}$target cell ratio of $30: 1$.

similar frequencies of $\mathrm{CD}^{+}$and $\mathrm{CD} 8^{+} \mathrm{T}$ cells as adult PBMC, there were marked differences in the distribution of functional subsets with cord blood CD4 ${ }^{+}$(Figure 2D) and $\mathrm{CD}^{+}{ }^{+} \mathrm{T}$ cells (Figure 2E) being predominantly naïve (naïve CD4: median 95\%, interquartile range 92-97\%; naïve CD8: median $89 \%$, interquartile range 84-94\%), and therefore deficient in memory and effector subsets. We hypothesized that although DART molecules are able to redirect resting T cells for killing of HIVinfected cells without need for pre-activation $(17,18)$, they may be more effective when redirecting effector or memory subsets. To test this, we assessed CD107a degranulation concomitant with redirected killing activity with PBMC from two healthy adult donors as a source of effector cells, and HIV-1 subtype B BaL IMC virus-infected cells as targets. We previously demonstrated high levels of HIV $\times$ CD3 DART molecule-induced $\mathrm{CD}^{+}$ $\mathrm{T}$ cell degranulation in the presence of $\mathrm{CD} 4^{+}$cells infected by this HIV-1 isolate (18). We found that although HIVspecific DART molecules induced degranulation in all subsets of $\mathrm{CD}^{+} \mathrm{T}$ cells during redirected cytotoxicity assays, the majority of degranulated cells were CCR7 ${ }^{-}$and therefore expressed phenotypes consistent with $\mathrm{T}_{\mathrm{EM}}$ and effector cells (Figure 2F). 
These data suggest that the reduced DART molecule-mediated cytotoxicity observed in assays performed using CBMC-derived $\mathrm{T}$ cells is likely due in part to the predominance of naïve cells in cord blood, and the absence of memory and effector CD8 ${ }^{+}$ $\mathrm{T}$ cells, which are preferentially redirected by the $\mathrm{HIV} \times \mathrm{CD} 3$ DART molecules.

\section{Evaluation of Strategies to Increase the Cytolytic Potential of T Cells in Cord Blood}

We explored strategies to increase the activity of cord blood cytolytic T cells for HIV DART molecule-redirected elimination of HIV-infected cells. We first evaluated the impact of priming CBMC-derived T cells with IL-12, as this cytotoxic-Tlymphocyte-promoting cytokine is known to be poorly expressed by the naïve infant immune system (41). We found that overnight incubation with exogenous IL-12, and maintenance of IL-12 treatment throughout the redirected cytotoxicity assay, did not improve cytotoxic activity of cord blood $\mathrm{CD}^{+} \mathrm{T}$ cells when used in combination with HIV $\times$ CD3 DART molecules (Figure 3A), nor was there any impact on activity of $\mathrm{CD} 8^{+} \mathrm{T}$ cells from adult PBMC. Next, reasoning that the naïve $\mathrm{CD} 8^{+} \mathrm{T}$ cells present in cord blood cells may require a more substantial activation signal compared to $\mathrm{CD}^{+} \mathrm{T}$ cells present in adult PBMC, we explored if killing activity could be improved by providing additional co-stimulatory signaling via co-engagement of CD28 or CD137 receptors (42). However, the results of experiments performed using T cells isolated from CBMC and adult PBMC demonstrated that exogenous anti-CD28 or anti-CD137 co-stimulation did not significantly improve killing mediated by HIV $\times$ CD3 DART molecules (Figure 3B). Moreover, we found that treatment of CBMC with IL-12 combined with anti-CD28 and anti-CD137 co-stimulation also had no impact on the cytolytic activity of $\mathrm{T}$ cells from CBMC when used with HIV $\times$ CD3 DART molecules, but did increase activity in assays performed with adult PBMC (Figure 3C), although the increase did not reach statistical significance ( $p=0.064$, Wilcoxon rank sum test). We next assessed if pre-activation of cord blood T cells would increase their cytotoxic activity. Interestingly, we found that preactivation of cord blood $\mathrm{T}$ cells via $\mathrm{T}$ cell receptor (TCR) cross linking using anti-CD3 and anti-CD28 monoclonal antibodies in combination with exogenous recombinant human IL-2 (30 $\mathrm{U} / \mathrm{mL}$ ) improved the ability of $\mathrm{T}$ cells from 5 of 5 tested cord blood samples to eliminate HIV-infected cells upon redirection by $7 \mathrm{~B} 2 \times \mathrm{CD} 3$ DART molecules, and 4 of 5 tested samples upon redirection by $\mathrm{A} 32 \times \mathrm{CD} 3 \mathrm{DART}$ molecules (Figure 3D). This observation indicates that $\mathrm{CD}^{+} \mathrm{T}$ cells present in cord blood are capable of improved cytotoxic activity when given sufficient stimulation.

We next determined if cord blood-derived $\mathrm{CD}^{+}{ }^{+}$cells, which had experienced prior activation and subsequently transitioned back to a resting state, were able to maintain higher cytolytic activity. To test this, we activated cord blood $\mathrm{CD}^{+} \mathrm{T}$ cells for $72 \mathrm{~h}$ via TCR stimulation as described above, then allowed the cells to rest for an additional $72 \mathrm{~h}$ before use in the redirected killing assay. Flow cytometry analysis was used to define cell phenotypes during activation, and the return to resting state as shown in Figures $\mathbf{4 A - C}$. As previously described, the preponderance of resting cord blood $\mathrm{CD} 8^{+} \mathrm{T}$ cell presented a naïve $\left(\mathrm{CD}_{45 \mathrm{RO}^{-}}, \mathrm{CCR}^{+}\right)$cell surface phenotype (Figure 4A). CD45RO expression increased along with expression of the activation markers CD69 and HLA-DR after TCR stimulation (Figure 4B). Upon returning to a resting state, cell-surface expression of activation markers CD69 and HLA-DR were reduced, but the vast majority of cells maintained a cell-surface phenotype consistent with that of $\mathrm{T}_{\mathrm{CM}}$ cells $\left(\mathrm{CD}_{45 \mathrm{RO}^{+}}, \mathrm{CCR}^{+}\right.$, Figure 4C). Despite these changes to cell-surface phenotypes, induced during activation and maintained after returning to rest, we observed similarly low levels of cytolytic activity for resting cord blood $\mathrm{CD}^{+} \mathrm{T}$ cells (Figure 4D), and $\mathrm{CD} 8^{+} \mathrm{T}$ cells that were transitioned from an active to resting state in vitro (Figure 4E). Collectively, these results demonstrated that redirected killing activity of cord blood $\mathrm{T}$ cells mediated by $\mathrm{HIV} \times \mathrm{CD} 3 \mathrm{DART}$ molecules was not affected by providing exogenous IL-12 or costimulatory signals, but could be improved when given sufficient stimulation leading to activation. However, the improved cytolytic activity was not maintained when activation waned.

\section{Cord Blood CD4 ${ }^{+}$T Cells Are Recruited by HIV x CD3 DART Molecules}

In parallel to the assays performed using CBMC-derived $\mathrm{CD}^{+}$ $\mathrm{T}$ cells as effector cells, we also evaluated whether HIV $\times$ CD3 DART molecules had anti-HIV activity when incubated with infected cord blood $\mathrm{CD}^{+}{ }^{+} \mathrm{T}$ cells alone. As the epitope recognized by the $7 \mathrm{~B} 2 \times \mathrm{CD} 3$ DART molecules is nonneutralizing (43) we expected minimal anti-HIV activity in absence of $\mathrm{CD}^{+}$effector cells. In contrast, we observed 7B2 $\times$ CD3 DART molecule-dependent specific killing of HIVinfected cells at similar levels for assays performed with and without $\mathrm{CD}^{+} \mathrm{T}$ cells from CBMC (Figure 5A, filled and open blue circles, respectively). We also observed 7B2 $\times$ CD3 DART molecule-dependent specific killing in assays performed without $\mathrm{CD}^{+} \mathrm{T}$ cells from PBMC (Figure 5A, open black squares), however killing was higher in the presence of PBMCderived $\mathrm{CD}^{+} \mathrm{T}$ cells (Figure 5A, filled black squares). To determine if $\mathrm{HIV} \times \mathrm{CD} 3 \mathrm{DART}$ molecules were capable of activating effector responses from the cord blood $\mathrm{CD} 4^{+} \mathrm{T}$ cells themselves, we assessed CD107a degranulation during redirected cytotoxicity assays as described previously. The gating strategy for identification of cord blood-derived CD $4^{+} \mathrm{T}$ cells in this assay is shown in Figure 5B, with representative flow cytometry plots depicting detection of CD107a on $\mathrm{CD}^{+}{ }^{+} \mathrm{T}$ cells in presence of control or HIV $\times$ CD3 DART molecules. These data demonstrate that $\mathrm{CD}^{+} \mathrm{T}$ cells from CBMC are capable of being induced to degranulate by DART molecules in redirected cytotoxicity assays. The specific killing activity observed using cord blood $\mathrm{CD}^{+}{ }^{+} \mathrm{T}$ cells as effectors to eliminate HIV-1 BaL-infected autologous $\mathrm{T}$ cells from two cord blood donations is shown in Figure 5C. The frequency of CD107a ${ }^{+} \mathrm{CD} 4^{+} \mathrm{T}$ cells detected in these assays is shown in Figure 5D. The specific killing and concomitant degranulation responses observed across the tested $\mathrm{HIV} \times \mathrm{CD} 3 \mathrm{DART}$ molecule concentrations show comparable 
A

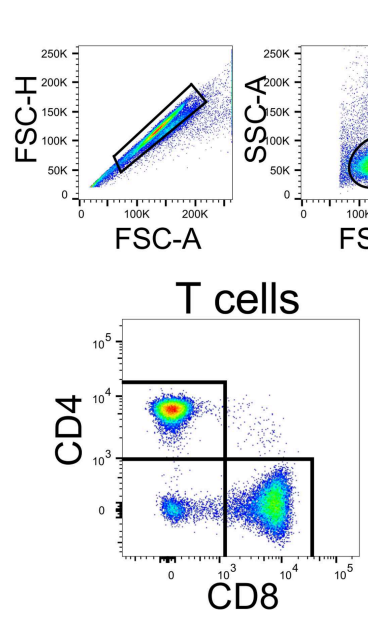

c

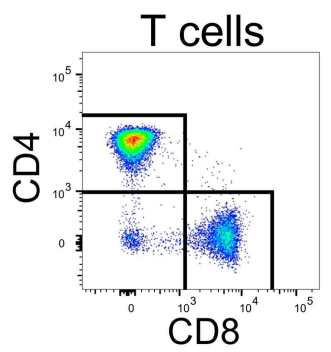

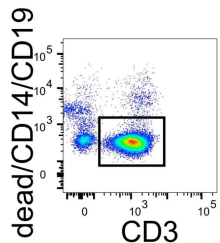

non-aggregate non-aggregate
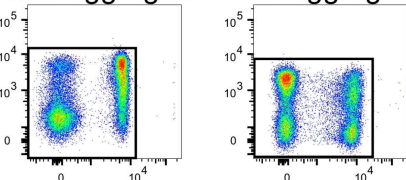

FSC-A 80 CD3
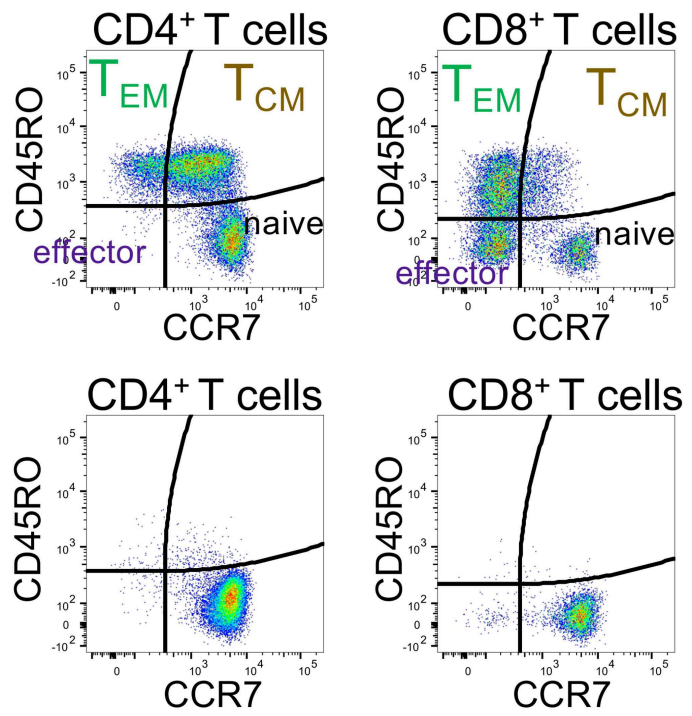

D

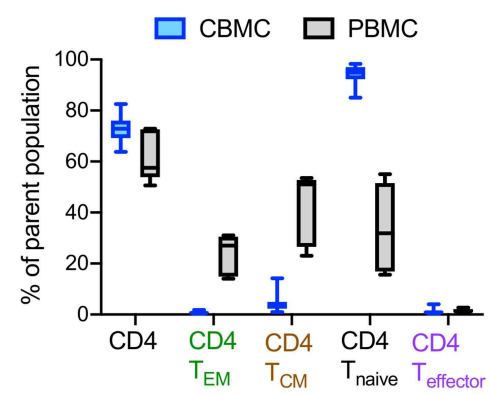

$\mathbf{E}$

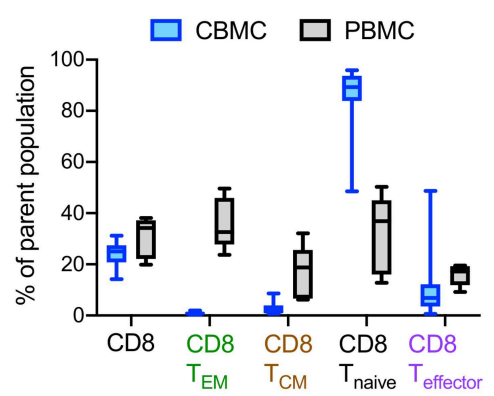

$\mathbf{F}$

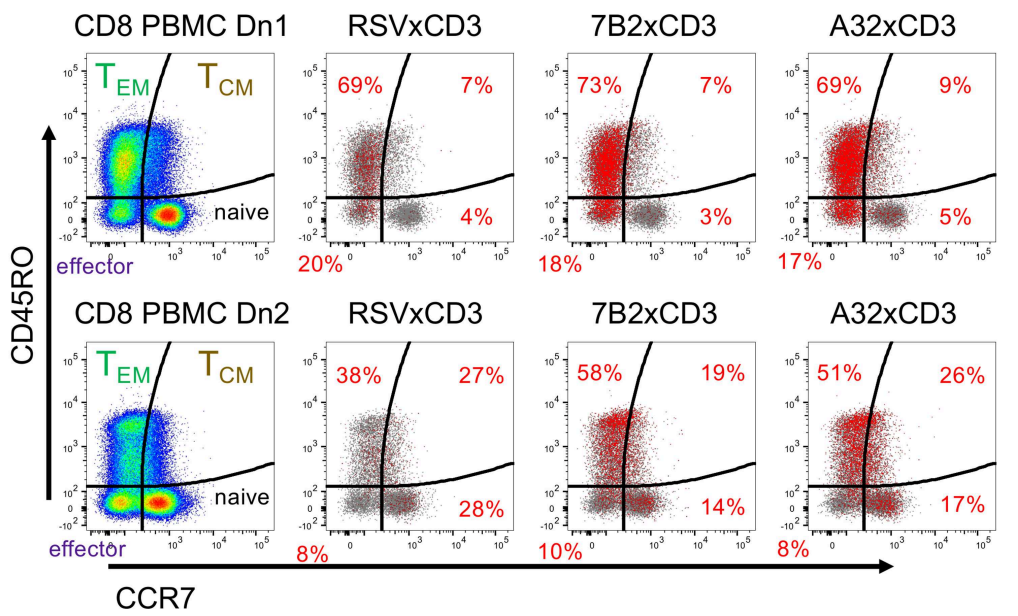

FIGURE 2 | Comparison of T cell subsets in adult peripheral blood mononuclear cells (PBMC) and cord blood mononuclear cells (CBMC) (A) Gating strategy. (B) Flow cytometry plots showing representative example of $\mathrm{CD}^{+}$and $\mathrm{CD}^{+} \mathrm{T}$ cell subsets among adult PBMC or (C) $\mathrm{CBMC}$. Comparison of frequencies of (D) total $\mathrm{CD} 4^{+} \mathrm{T}$ 
FIGURE 2 | Cells and CD4 $4^{+}$T cell subsets or $(\mathbf{E}) \mathrm{CD}^{+}$T cells and CD8 ${ }^{+}$T cell subsets in CBMC $(n=14)$ and adult PBMC $(n=5)$. In $(\mathbf{D}, \mathbf{E})$, box plots represent the interquartile ranges, horizontal lines indicate the medians, and error bars extend to the minimum and maximum observed values. (F) CD8 ${ }^{+} \mathrm{T}$ cells subsets that degranulate concomitant with HIV $\times$ CD3 or control (RSV $\times$ CD3) DART molecule mediated cytolytic activity. Rows represent assay results using PBMC from two different adult donors, Dn1 and Dn2. Distribution of $\mathrm{CD}^{+} \mathrm{T}$ cell subsets is shown in the first column. Red dots in the remaining columns represent CD8 T cells that have degranulated $(\mathrm{CD} 107 \mathrm{a}+)$ in response to the indicated DART molecules (frequencies within each quadrant indicated with red text), overlaid on the total $\mathrm{CD} 8^{+} \mathrm{T}$ cells (gray dots) acquired for each condition. $24 \mathrm{~h}$ killing assay with a CD8 ${ }^{+}$effector to Bal-infected autologous $\mathrm{CD} 4^{+}$target cell ratio of 30:1 and DART molecule concentration of $100 \mathrm{ng} / \mathrm{mL}$.
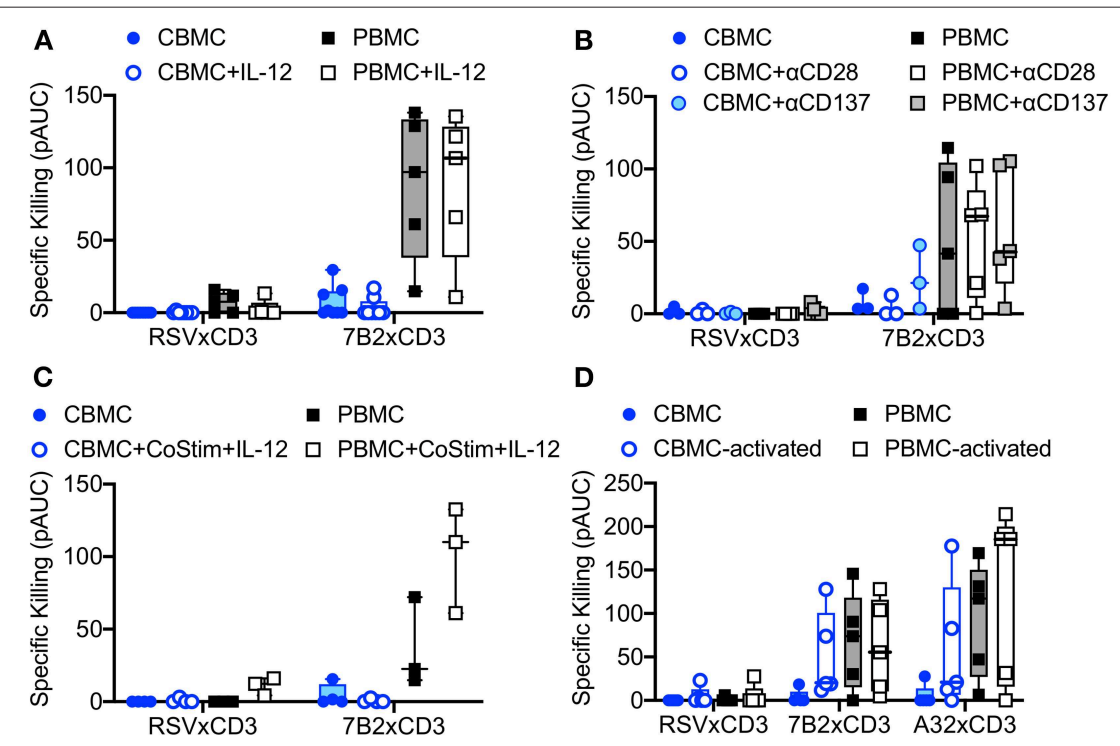

FIGURE 3 | Redirection of cord blood mononuclear cell (CBMC)-derived cytolytic T cells for elimination of autologous HIV-1 infected CD4 T cells by HIV $\times$ CD3 DART molecules is not improved by incubation with (A) $10 \mathrm{ng} / \mathrm{mL}$ exogenous IL-12 (CBMC $n=8$, PBMC $n=5$ ), (B) costimulation with anti-CD28 or anti-CD137 antibodies (CBMC $n=3, \mathrm{PBMC} n=5$ ), or (C) a combination of costimulation with anti-CD28 and anti-CD137 (CoStim) and exogenous IL-12 (CBMC $n=4$, PBMC $n=3$ ). (D) HIV $\times$ CD3 DART molecule-mediated elimination of autologous HIV-1-infected CD4 ${ }^{+} T$ cells is improved when $C D 8^{+} T$ cells used as effectors are activated by $T$ cell receptor stimulation (anti-CD28, anti-CD3, and IL-2) for $48 \mathrm{~h}$ prior to use in the cell killing assays (CBMC and PBMC $n=5$ ). Box plots represent the interquartile ranges, horizontal lines indicate the medians, and error bars extend to the minimum and maximum observed values. $24 \mathrm{~h}$ killing assays with a CD8 ${ }^{+}$effector to $\mathrm{HIV}^{-1}$ 4403bmC5-infected autologous CD4+ target cell ratio of 30:1. All data reported as positive area under the dilution curve (pAUC).

trends, suggesting that degranulating $\mathrm{CD} 4^{+} \mathrm{T}$ cells contribute to the in vitro elimination of $\mathrm{HIV}-1$ infected cells when redirected by HIV $\times$ CD3 DART molecules. This finding is consistent with observations made in our prior studies performed using adult PBMC (18).

\section{HIV x CD16 DART Molecules Can Recruit Cord Blood NK Cells for Elimination of Autologous HIV-1 Infected CD4 ${ }^{+}$T Cells}

Another approach for increasing HIV DART-molecule-mediated elimination of HIV-1 infected cells is to recruit additional populations of cytotoxic effector cells. We used flow cytometry immunophenotyping to compare NK cells present in CBMC and adult PBMC according to the gating strategy shown in Figure 6A. We found that cord blood contains more total NK cells (median $11 \%$ total $\mathrm{NK}$ in CBMC and 5\% in adult PBMC), but similar distributions of $\mathrm{NK}$ cell subsets, as adult peripheral blood (Figure 6B). As we, and others, have previously demonstrated that pretreatment with IL-15 augments the cytotoxic potential of NK cells $(32,44-46)$ we compared the impact of overnight incubation with IL-15 $(10 \mathrm{ng} / \mathrm{mL})$ on the subset distribution, activation state, and intracellular abundance of cytotoxic effector molecules in NK cells present in CBMC and adult PBMC. We previously showed that IL-15 treatment increased the frequency of CD56 $6^{\text {bright }} \mathrm{NK}$ cells and $\mathrm{CD} 56^{\text {dim }} \mathrm{CD} 16^{-/ \mathrm{dim}} \mathrm{NK}$ cells, and decreased $\mathrm{CD} 56^{\mathrm{dim}} \mathrm{CD} 16^{+} \mathrm{NK}$ cells in adult PBMC [(32) and Figure 6B]. The impact of IL-15 on cord blood NK cell subset distributions was modest, with no significant change (Wilcoxon rank sum tests) in the frequencies of major NK cell subsets (Figure 6B). Importantly, the cytotoxic CD $56^{\mathrm{dim}} \mathrm{CD} 16^{+} \mathrm{NK}$ cell subset was the dominant population of NK cells in both cord blood and adult PBMC. As we previously described for IL-15 treated NK cells in adult PBMC, we found that IL-15 treatment did not impact the expression of the maturation marker CD57 on the surface of cord blood NK cells, although its expression was markedly lower than that observed on NK cells in adult PBMC ( $p<0.001$, Wilcoxon rank sum test), which is consistent with the naivety of cord blood immune cells (Figure 6C). We also found that fewer cord blood NK cells expressed the secondary lymphoid homing marker CD62L when compared to NK cells in adult PBMC ( $p<0.001$, Wilcoxon rank sum test), and treatment of cord blood with IL-15 further reduced the percentage of 

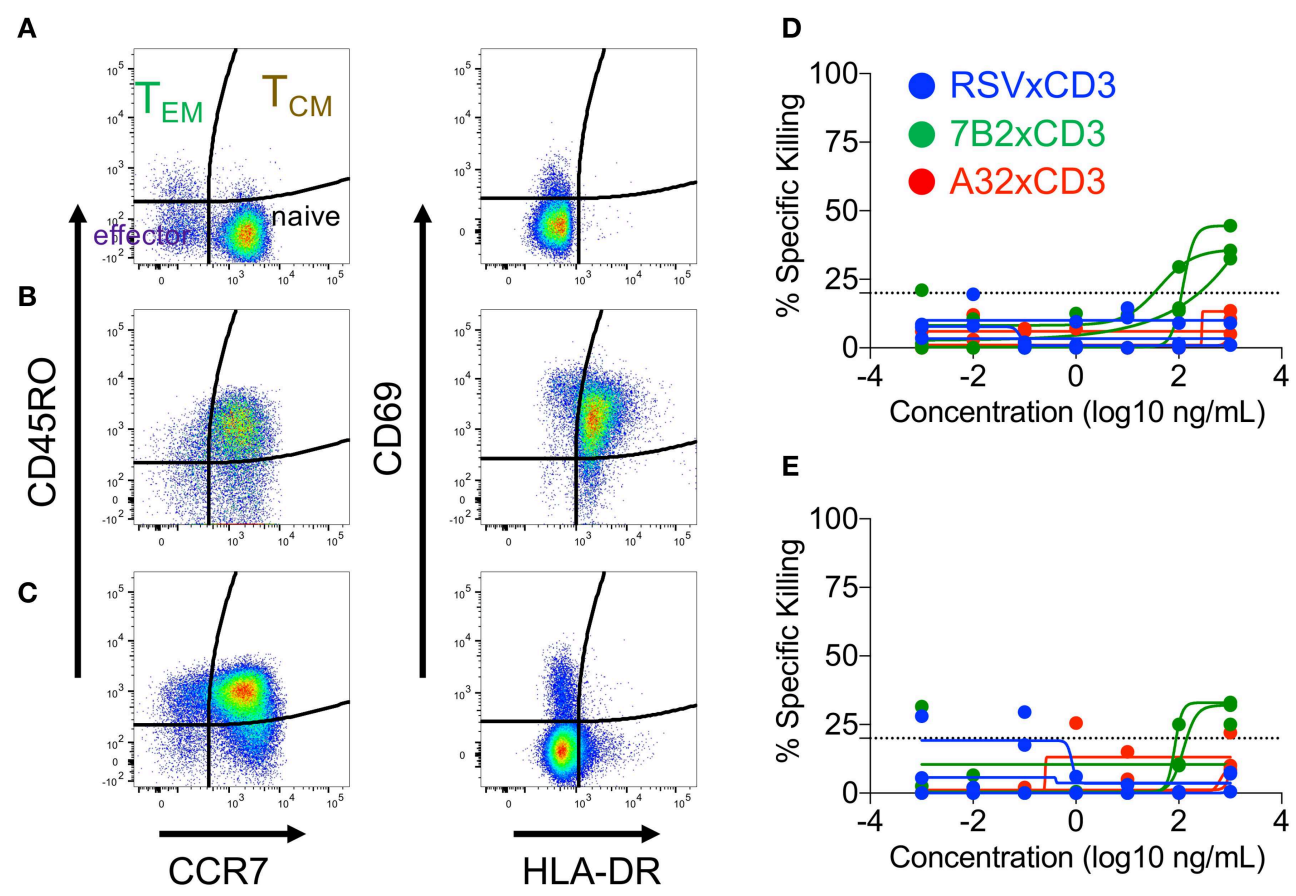

FIGURE 4 | Cord blood mononuclear cell (CBMC) CD8 ${ }^{+}$T cells subset distribution (left panels) and activation state (right panels) after (A) overnight rest, (B) 3 days of T cell receptor stimulation (anti-CD3, anti-CD28, and IL-2), or (C) 3 day transition from activated cells back to the resting state. Representative example shown. Similar

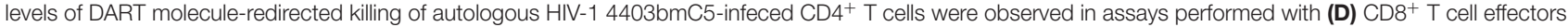
after overnight rest, and $(\mathbf{E})$ as they returned back to a resting state following 3 days of $\mathrm{T}$ cell receptor stimulation. (D,E) represent data from $24 \mathrm{~h}$ killing assays with a $\mathrm{CD}^{+}$effector to HIV-1 4403bmC5-infected autologous CD4+ target cell ratio of 30:1, performed using three different CBMC donors, each represented by individual lines.

NK cells expressing CD62L (Figure 6D). Moreover, and as expected, cord blood NK cells incubated with IL-15 presented a more active phenotype than untreated NK cells as evident by cell surface expression of HLA-DR (Figure 6E) and CD69 (Figure 6F), although overall, the frequency of activated NK cells was lower in CBMC compared to adult PBMC following IL-15 treatment $(p<0.001$ for both CD69 and HLA-DR, Wilcoxon rank sum tests). Finally, using fluorescent quantitation beads to measure the intracellular content of perforin and granzyme $B$, we found that cord blood NK cells contained more perforin (Figure 6G) but less granzyme B (Figure 6H) than NK cells in adult PBMC, whether untreated (perforin, $p=0.001$; granzyme $\mathrm{B}, p<0.001$, Wilcoxon rank sum tests) or treated with IL-15 (granzyme B, $p<0.001$, Wilcoxon rank sum test). Collectively, these data suggest that cord blood contains similar distributions of NK cell subsets as adult peripheral blood, however the NK cells present in cord blood are less mature, less lymphoid homing, less active, and contain less of the cytotoxic effector molecule granzyme B when compared to NK cells in adult PBMC.

To recruit and redirect NK cells, DART-molecules comprised of our previously characterized HIV-1 targeting arms (18) linked to CD16 targeting arms were developed. We used flow cytometry staining to confirm that DART-molecules with CD16-targeting arms were capable of binding to the surface of human NK cells (Figure 7A). We next evaluated the ability of cord blood NK cells to eliminate autologous $\mathrm{CD}^{+}{ }^{+} \mathrm{T}$ cells infected with $\mathrm{HIV}-1$
4403 bmC5 virus when redirected by HIV $\times$ CD16 (clone hG38) DART molecules based on the 7B2 mAb. Similar to the data observed for cord blood $\mathrm{CD} 8^{+} \mathrm{T}$ cells, we found that resting cord blood NK cells had modest ability to eliminate autologous HIV-1 infected $\mathrm{T}$ cells when redirected by the $7 \mathrm{~B} 2 \times \mathrm{CD} 16$ DART molecule (Figure 7B, filled symbols). However, overnight treatment with IL-15 significantly increased ( $p=0.007$, Wilcoxon rank sum test) the cytotoxic activity of cord blood NK cells when redirected by the HIV-specific DART molecule (Figure 7B, open symbols). The 7B2 $\times$ CD16 DART molecule redirected cytolytic activity of IL-15 treated CBMC NK cells was similar to that observed in assays performed with NK cells from adult PBMC (Figure 7B, black squares). These data demonstrate that NK cells in cord blood have potential to be effective mediators of DART molecule-redirected killing after priming with IL-15. We next explored whether combinations of HIV $\times$ CD16 DART molecules specific for different epitopes improved elimination of HIV-infected cells. For these experiments, we used HIV $\times$ CD16 DART molecules $(\mathrm{A} 32 \times \mathrm{CD} 16$ and 7B2 $\times$ CD16) and a control molecule $(\mathrm{RSV} \times \mathrm{CD} 16)$ that were generated using a different anti-CD16 arm (clone h5H2, Figure 7A). Assays were performed using NK cells from three cord blood samples that we identified as having cytolytic activity in previous assays. Using equivalent concentrations of the A32 $\times$ CD16 and 7B2 $\times$ CD16 molecules we found that activity of the combination was similar to that of the A32 × CD16 molecule alone (Figure 7C). Thus, there was no 


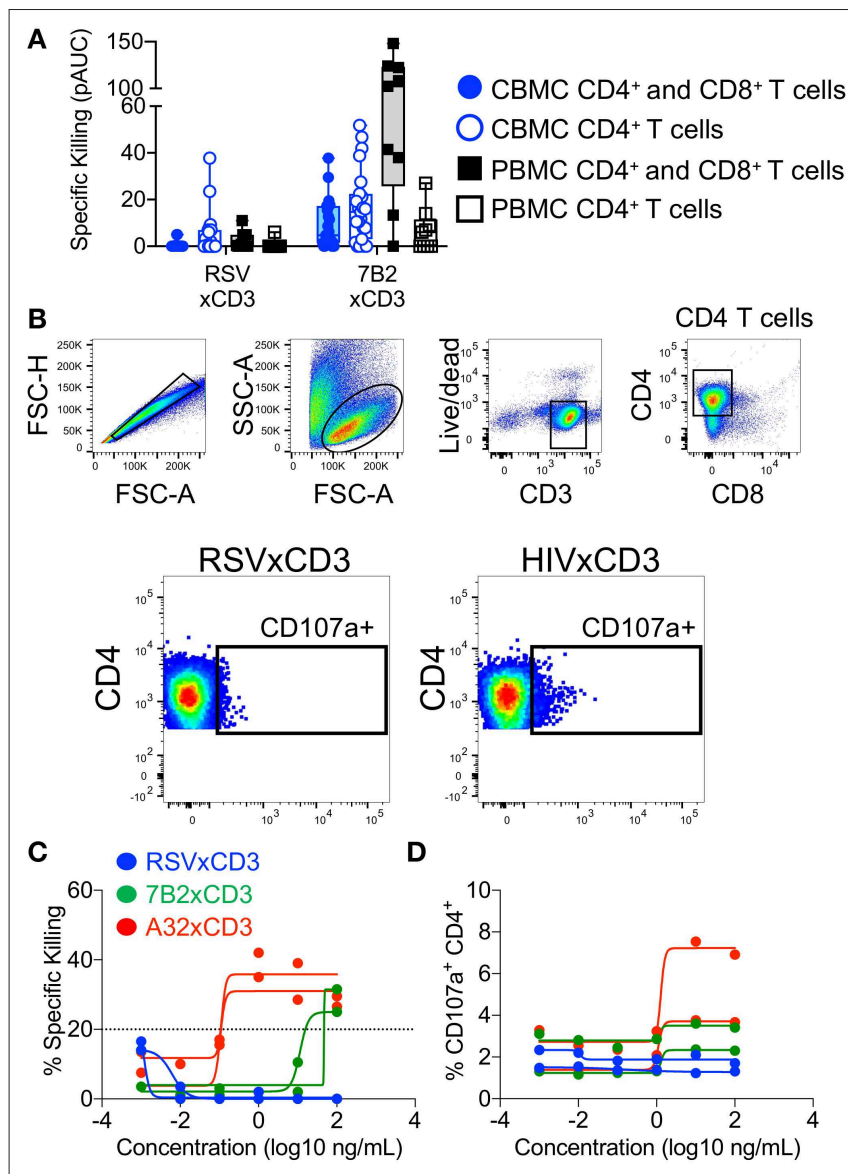

FIGURE 5 | Redirection of cord blood mononuclear cell (CBMC)-derived $\mathrm{CD}^{+} \mathrm{T}$ cells for elimination of HIV-infected cells by HIV $\times \mathrm{CD} 3$ or control (RSV $\times$ CD3) DART molecules. (A) Similar levels of HIV-1 4403bmC5 infected CBMC-derived $\mathrm{CD}^{+}{ }^{+} \mathrm{T}$ cell killing were observed in assays performed with autologous $\mathrm{CD}^{+} \mathrm{T}$ cell effectors (filled blue circles and box, $n=23 \mathrm{CBMC}$ samples) or with $\mathrm{CD}^{+}{ }^{+} \mathrm{T}$ cells alone, no additional effector cells (open blue circles and box). HIV-1 4403bmC5 infected PBMC-derived CD4 ${ }^{+} \mathrm{T}$ cell killing observed in assays performed with autologous $\mathrm{CD}^{+} \mathrm{T}$ cell effectors (filled black squares and box, $n=9$ PBMC samples) or with $\mathrm{CD}^{+}{ }^{+} \mathrm{T}$ cells alone, no additional effector cells (open black squares and box). (B) Gating strategy used to identify cord blood CD4 ${ }^{+}$T cells that degranulated concomitant with DART molecule mediated cytolytic activity. Redirection of CBMC-derived $\mathrm{CD}^{+}{ }^{+} \mathrm{T}$ cells for elimination of HIV-1 Bal-infected autologous CD4 ${ }^{+} \mathrm{T}$ cells as measured by (C) luciferase cell killing assay, and (D) CD107a degranulation assay. Data are from $24 \mathrm{~h}$ killing assays performed using two different CBMC donors, each represented by individual lines.

evidence in these assays of an additive effect, nor of interference, when using these two HIV $\times$ CD16 DART molecules to mediate redirected killing with cord blood NK cells.

Finally, we investigated whether combinations of HIV $\times \mathrm{CD} 3$ and HIV $\times$ CD16 DART molecules could work cooperatively for improved killing. To test this, we utilized IL-15 treated CBMC from two donors which we identified as having $\mathrm{T}$ cells and NK cells that supported redirected killing of autologous HIV-infected $\mathrm{CD}^{+}{ }^{+} \mathrm{T}$ cells. $7 \mathrm{~B} 2 \times \mathrm{CD} 3$ and $7 \mathrm{~B} 2 \times \mathrm{CD} 16$ DART-molecules were used either alone, or in combination at equivalent concentrations. RSV $\times$ CD 3 and $4420 \times$ CD16 DART molecules in equivalent combination were used as a negative control. As shown in Figure 7D, combinations of 7B2 $\times$ CD3 and 7B2 $\times$ CD16 DART molecules did not improve the killing of HIV-1-infected autologous $\mathrm{CD} 4^{+} \mathrm{T}$ cells by cord blood cells in these assays.

\section{DISCUSSION}

Mother-to-child transmission is the principal cause of the approximate 400 new pediatric HIV-1 infections that occur each day, mostly in resource limited countries (4). Infants born into these unfortunate circumstances must strictly adhere to a lifetime of ART to control virus replication and prevent disease progression. Thus, there is a critical need for innovative therapeutic approaches enabling long-term remission or cure of infant HIV-1 infection in order to offer these children the chance to lead normal, healthy lives. One potential strategy is the use of antibody-based immunotherapy in combination with ART and latency reversing agents as a "shock and kill" approach to eliminate the virus reservoir $(15,16,47,48)$. Infants are potentially ideal candidates for immunotherapy due to the ability to initiate therapy soon after the perinatal transmission event and prior to establishment of a large virus reservoir $(49,50)$, and proven history of safe administration of passive antibody therapy against another infectious disease, respiratory syncytial virus (51). Here, we used human umbilical cord blood as a surrogate model of neonatal peripheral blood to test the hypothesis that $\mathrm{HIV} \times \mathrm{CD} 3 \mathrm{DART}$ molecules based on HIV-specific mAbs could redirect neonatal effector cells for elimination of cells infected with HIV-1. Importantly, our in vitro assays used autologous cord blood-derived $\mathrm{CD} 4^{+} \mathrm{T}$ cells as target cells, after infecting with an HIV IMC molecular clone virus encoding an HIV-1 subtype C env gene sequenced from plasma of a postnatally-infected infant, and identical to an isolate found in the matched maternal breast milk (34). Thus, these assays attempt to recapitulate the effector cells and HIV-1 Env-expressing target cells expected to be present in perinatally infected infants. Our results demonstrated that $\mathrm{T}$ cells present in cord blood can be recruited and redirected by $\mathrm{HIV} \times \mathrm{CD} 3 \mathrm{DART}$ molecules to eliminate HIV-1 infected target cells. This key finding supports the continued development of HIV-specific DART molecules as immunotherapies to combat pediatric HIV infection. However, we also found that the DART molecule-dependent killing activity by $\mathrm{T}$ cells from cord blood is significantly lessened as compared to that by $\mathrm{T}$ cells from adult PBMC. We therefore explored approaches to improve the cytotoxicity of cord blood effector cells with the goal of identifying strategies to maximize the potential effectiveness of DART molecule-based immunotherapy for use in early life.

We found that cord blood $\mathrm{T}$ cells were largely refractory to in vitro cytokine treatment and co-stimulatory receptor engagement intended to increase their cytolytic activity. We observed no impact of exogenous IL-12 (41), CD28 and CD137 co-stimulatory receptor engagement via specific antibodies, nor of combined use of IL-12 and co-stimulatory receptor engagement on the ability of cord blood $\mathrm{T}$ cells to eliminate HIV-1 infected cells when redirected by $\mathrm{HIV} \times \mathrm{CD} 3 \mathrm{DART}$ 

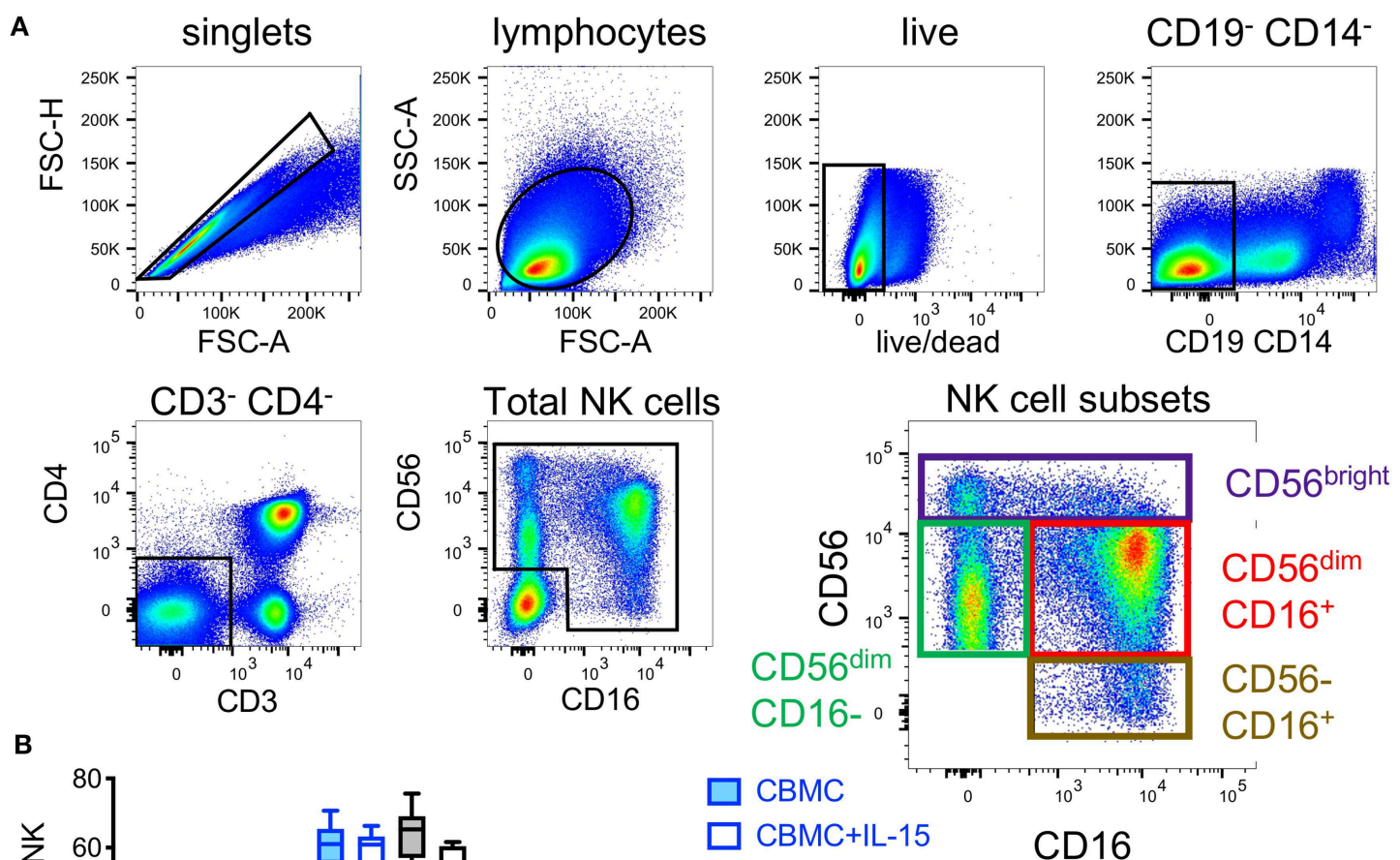

B
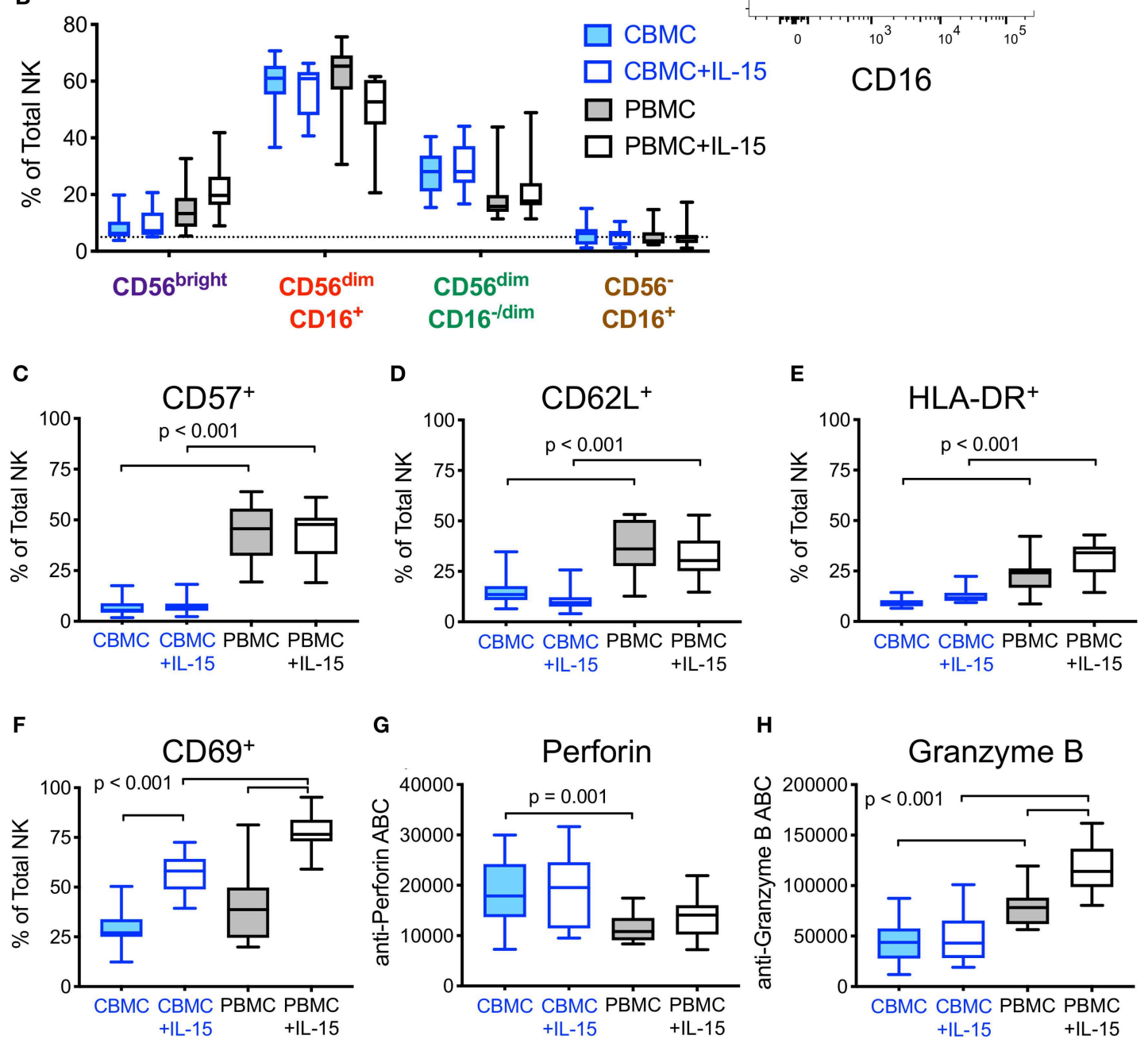

G

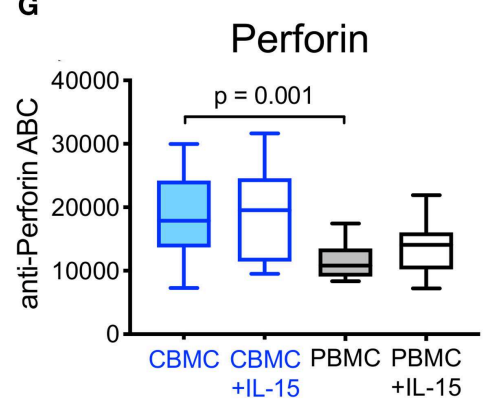

H

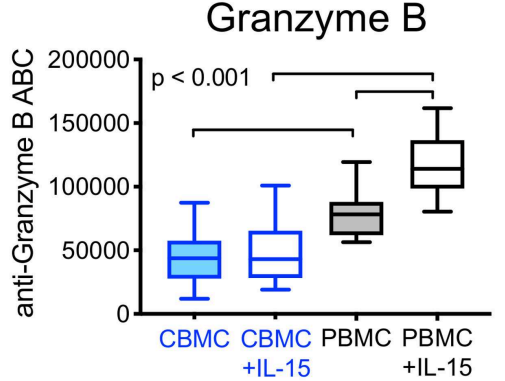

FIGURE 6 | Effect of exogenous IL-15 treatment on phenotypes of natural killer (NK) cells present in cord blood mononuclear cells (CBMC) with comparison to adult peripheral blood (PBMC). (A) Gating strategy used to identify total and subsets of NK cells. Data representing all CBMC samples $(n=30,15 \mathrm{CBMC}$ donors $+/$ - IL-15) 
FIGURE 6 | were combined and included in the flow cytometry plots shown. (B) Comparison of NK cell subset frequencies between untreated, and after overnight treatment with $10 \mathrm{ng} / \mathrm{mL} \mathrm{IL}-15$ ( $n=15 \mathrm{CBMC}$ and $n=15 \mathrm{PBMC}$ samples per condition). Frequencies of total NK cells expressing (C) CD57, (D) CD62L, (E), HLA-DR, and (F) CD69 in cells left untreated or treated overnight with $10 \mathrm{ng} / \mathrm{mL} \mathrm{IL-15}$. Amount of intracellular (G) Perforin and (H) Granzyme B in NK cells left untreated or after overnight treatment with $10 \mathrm{ng} / \mathrm{mL} \mathrm{IL}-15$, measured by antibody binding capacity (see Methods). In (B-H), box plots represent the interquartile ranges, horizontal lines indicate the medians, and error bars extend to the minimum and maximum observed values.
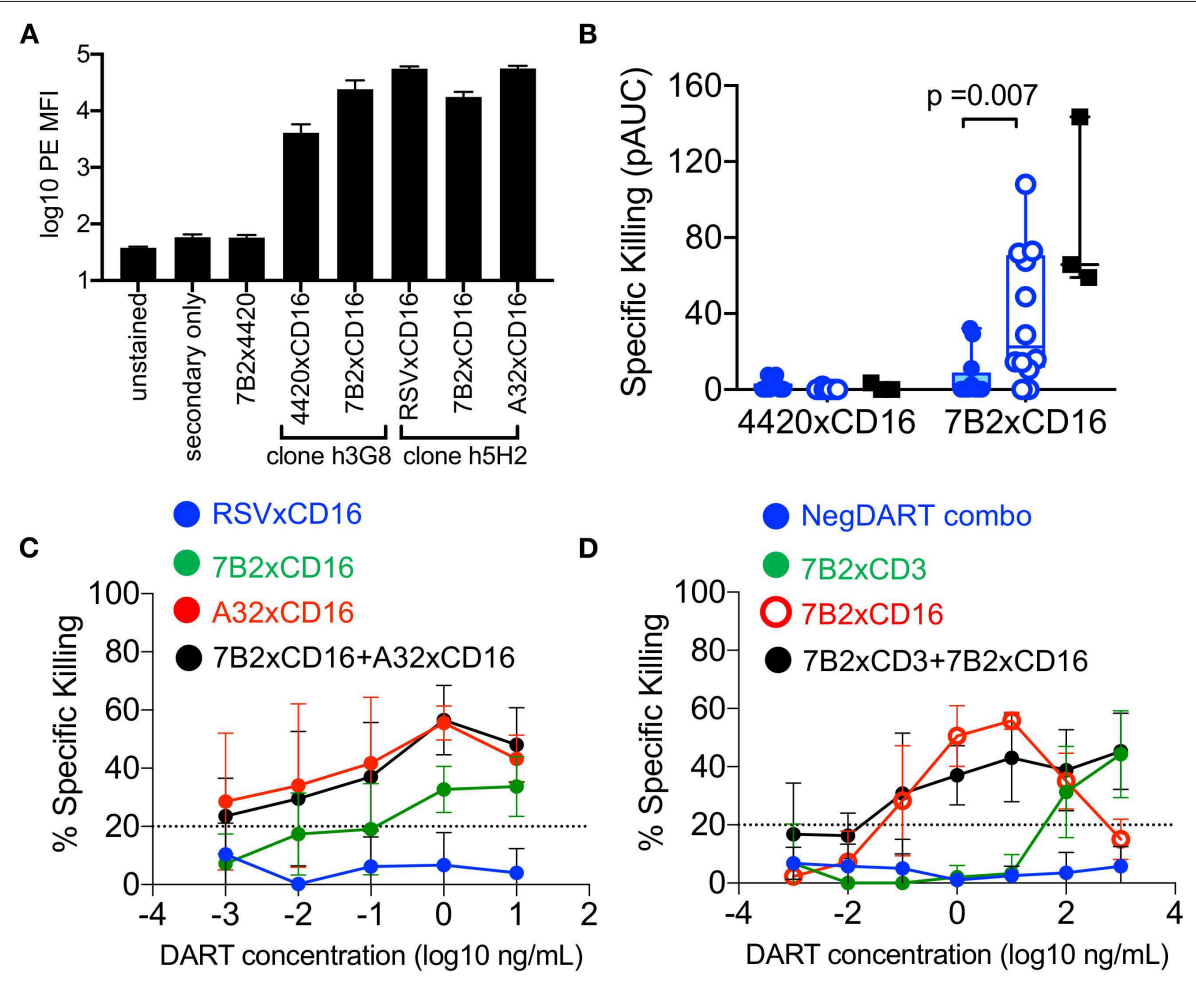

FIGURE 7 | (A) DART-molecules with CD16-targeting arms bind to the surface of human NK cells (from $n=4$ donors) by flow cytometry analysis. Data are reported as mean fluorescent intensities (MFI), error bars represent standard deviation. (B) Redirection of cord blood mononuclear cell (CBMC)-derived NK cells (from $n=12$ CBMC samples, blue circles) for elimination of HIV-1 4403bmC5-infected autologous CD4+ T cells by 7 B2 $\times$ CD16 or control (4420 $\times$ CD16) DART molecules in the absence of IL-15 (filled symbols) or after overnight incubation with $10 \mathrm{ng} / \mathrm{mL} \mathrm{IL-15}$ (open symbols). Results of assays performed with adult NK cells from three PBMC samples, in absence of IL-15, are included for comparison (black filled squares). Data are positive area under the dilution curve (pAUC) from $24 \mathrm{~h} \mathrm{killing} \mathrm{assays} \mathrm{with} \mathrm{a}$ NK cell to CD4+ T cell ratio of 5:1. (C) Similar levels of HIV $\times$ CD16 DART molecule-redirected killing of autologous HIV-1 4403bmC5-infeced CD4+ T cells were observed in assays performed with A32 $\times$ CD16 DART molecules and A32 $\times$ CD16 DART molecules combined with 7B2 $\times$ CD16 DART molecules $(n=3$ CBMC-derived, IL-15 treated, NK cell samples, assayed in duplicate). (D) Redirection of CBMC ( $n=2$ samples, assayed in duplicate) for elimination of HIV-1 4403bmC5-infected autologous CD4 ${ }^{+}$T cells by 7B2 x CD3 DART molecules, 7B2 × CD16 DART molecules, or 7B2 x CD3 and 7B2 x CD16 DART molecules used in combination. Twenty four hours killing assay with an IL-15 treated whole CBMC to CD4+ T cell ratio of 30:1. Data in (C,D) represent mean +/- standard deviation.

molecules. However, DART molecule-mediated cytolytic activity was increased when cord blood $\mathrm{T}$ cells were activated by TCR stimulation in the presence of IL-2. This result suggests that neonatal $\mathrm{T}$ cells have the capability to be potent cytolytic effectors if given sufficient activation signals. We also found that cells transitioned in vitro from an activated state back to a resting state had similar cytolytic activity to cells that had not experienced activation, suggesting that transient activation did not result in a durable change in the cytolytic potential of cord bloodderived $\mathrm{CD}^{+} \mathrm{T}$ cells. Comparative studies using cells from adult peripheral blood demonstrated that HIV $\times$ CD3 DART molecules effectively recruit and redirect memory and effector $\mathrm{T}$ cells - populations of cells that are poorly represented in cord blood. Thus, the limited maturation of $\mathrm{T}$ cell subsets in cord blood likely explains the observed reduced activity when compared to adult immune cells. However, it is important to consider that our in vitro cord blood-based experiments fail to fully model the diversity of $\mathrm{T}$ cell activation states and functional subsets present in an infant in vivo. Several lines of evidence suggest that $\mathrm{T}$ cells from pediatric peripheral blood may be more phenotypically and functionally diverse than those from cord blood. First, maternal and/or perinatal infant infections with cytomegalovirus and Trypanosoma cruzi, have been found to promote $\mathrm{T}$ cell maturation in utero and during infancy $(52,53)$. As cytomegalovirus, T. cruzi, and a myriad of other infectious agents and parasites are endemic in regions of high HIV-1 prevalence (54), it is likely that infants infected with HIV-1 via mother-to-child transmission have circulating $\mathrm{T}$ cells that differ 
in maturation, activation, and functionality when compared to those in cord blood from healthy United States-based mothers, as utilized in this study. It also has been shown that there are differences between pediatric circulating $\mathrm{T}$ cells, as modeled by cord blood in this study, and $\mathrm{T}$ cells present in pediatric tissues. Seminal work by Thome and collaborators using tissues obtained from pediatric organ donors from 2 months to 2 years of age demonstrated that, although naïve cells constitute the majority of $\mathrm{T}$ cells in pediatric peripheral blood, spleen, and lymph nodes, $\mathrm{T}_{\mathrm{EM}}$ cells comprise a large portion of the $\mathrm{T}$ cells in intestinal mucosal tissues (40). Moreover, they demonstrated that memory $\mathrm{T}$ cells from the intestine were capable of rapid secretion of the effector cytokine IFN $\gamma$ in response to stimulation. Because we found that $\mathrm{T}_{\mathrm{EM}}$ cells are preferentially recruited by HIV $\times$ CD3 DART molecules, the cytolytic activity of these molecules mediated by tissue-derived T cells at mucosal sites may be higher than that observed by cord blood-derived $\mathrm{T}$ cells in vitro. It is important to note that Thome and collaborators also identified higher frequencies of $\mathrm{T}$ regulatory cells in pediatric blood and tissues relative to adults (40). The $\mathrm{CD} 4^{+} \mathrm{T}$ regulatory cells may act to either limit the cytolytic activity of infant $\mathrm{T}$ cell responses, or may themselves serve as effector cells for CD3 DART molecule-mediated lysis of target cells as has been previously shown (55). Thus, accurate characterization of the cytolytic activity of pediatric tissue-resident $\mathrm{T}$ cells when recruited by $\mathrm{HIV} \times \mathrm{CD} 3 \mathrm{DART}$ will likely require in vivo testing using a biologically relevant model, such as infant rhesus macaques. Finally, immune system development during early life will likely also affect the therapeutic potential of $\mathrm{HIV} \times \mathrm{CD} 3$ DART molecules. In fact, $\mathrm{CD}^{+} \mathrm{T}$ cell responses may mature rather quickly, as young children (2-3 years of age) have been shown to have $\mathrm{CD} 8^{+} \mathrm{T}$ cells with potent antiviral activity $(56,57)$. These observations suggest that the ability of HIV $\times$ CD3 DART molecules to mediate elimination of HIV-1-infected cells may improve over the first few years of life. Interestingly, we also found that cord blood $\mathrm{CD} 4^{+} \mathrm{T}$ cells contributed to elimination of infected cells in vitro. Whether these cells would contribute to $\mathrm{HIV} \times \mathrm{CD} 3 \mathrm{DART}$ molecule-dependent elimination of infected cells in vivo is not yet known. Additional studies using blood samples collected longitudinally from HIV-infected infants and age-appropriate non-human primate models would likely help to identify relevant populations of effector cells, and to determine the optimal timing post birth for usage of HIV $\times$ CD3 DART molecules to eliminate the HIV-1 infected cell reservoir during early life. However, the presence of higher birth levels of memory $\mathrm{T}$ cells, and rapid expansion of $\mathrm{T}$ cell memory in rhesus macaques may complicate human translation of such studies (58).

Effective control and/or cure of pediatric HIV will likely require early and aggressive interventions. Thus, the likelihood of success with the HIV-specific DART molecule-based approach might be increased by recruitment of additional populations of cytolytic effector cells to further promote eradication of infected cells, and to potentially reach additional tissues and anatomical compartments. NK cells are abundant in cord blood and pediatric peripheral blood, with cytotoxic $\mathrm{CD} 56^{\mathrm{dim}} \mathrm{CD} 16^{+}$ NK cells representing the dominant subset $(39,45,59)$. We found that HIV $\times$ CD16 DART molecules were able to recruit and redirect neonatal NK cells present in cord blood for elimination of HIV-1 infected cells and killing activity could be substantially increased by treatment with IL-15. The ability of IL-15 to augment the cytolytic activity of cord blood derived $\mathrm{NK}$ cells is consistent with previously reported results from assays measuring cord blood NK cell natural cytotoxicity against sensitive target cells (45). Currently, the mechanisms by which IL-15 improves NK cell cytotoxicity are incompletely defined. We previously demonstrated that IL-15 treatment of NK cells from adult peripheral blood increases the levels of cytolytic effector molecules, perforin and granzyme B (32). By contrast, we found that cord blood NK cells contained more perforin, but less granzyme B, than NK cells in adult PBMC - and the levels of neither were impacted by IL-15 treatment. Thus, intracellular abundance of perforin and granzyme B does not explain how cord blood NK cells become more cytolytic after incubation with IL-15, which suggests involvement of other activatory or regulatory processes. Exogenous IL-15 was previously shown to increase cord blood NK cell expression of intracellular adhesion molecule 1 (ICAM-1) - a cell surface protein involved in cellto-cell interactions including formation of NK cell immunologic synapses (60). However, this effect was only seen after extended culture for 7 days (61), not after a short overnight incubation as in our study. It has also been proposed that the higher frequency of cord blood NK cells expressing cell-surface inhibitory receptor NKG2A compared to NK cells from adult peripheral blood may contribute to the reduced activity of cord blood derived NK cells (62). In contrast, we have previously demonstrated that IL15 promotes expression of the activating receptors NKG2D and NKp30 (46). Additional research will be required to define the impact of IL-15 on the multitude of cord blood NK inhibitory and activating receptors, and to determine how these signals may integrate with the CD16-mediated signaling that occurs when NK cells interact with HIV x CD16 DART molecules.

Having found that IL-15 stimulation is able to maximize the functionality of cord blood NK cells for DART moleculeredirected killing has generated another important question: are neonatal NK cells naturally primed by IL-15 in vivo during HIV1 infection? IL-15 was transiently detected in the plasma during acute HIV-1 infection of adults, with a median time of first detection being 6 days after viremia reached detectable levels in peripheral blood plasma (63). Although a similar inflammatory cytokine response is expected in neonates, it has also been demonstrated that stimulated CBMC produce less IL-15 than adult peripheral blood (64). Whether or not sufficient levels of IL-15 to activate neonatal NK cells would be present at sites of infection will require additional research. If an absence of natural IL-15 is identified, alternative strategies including the administration of recombinant human IL-15, or engineered forms of IL-15 $(65,66)$, in combination with the HIV $\times$ CD16 DART molecules could be tested in the infant rhesus macaque model.

Although we found that combinations of $7 \mathrm{~B} 2 \times \mathrm{CD} 3$ and A32 $\times$ CD3 DART molecules did not result in improved cytolytic activity, it is important to note that these studies were intended to explore the cytolytic potential of neonatal effector cells, not to identify optimal combinations of DART molecules. We 
used 7B2 and A32 DART molecules as an extension of our original study (18), but additional DART molecules targeting other Env epitopes have been described (17). It is probable that combinations of DART molecules targeting both broadbinding neutralizing and non-neutralizing epitopes, could be the most effective in recognizing the HIV Env diversity that results from the genetic diversity of $\mathrm{HIV}-1$, and the variety of Env conformations that may be found on the surface of infected cells in vivo $(43,67,68)$. Research aimed at identifying optimal combinations of anti-HIV antibodies using diverse HIV isolates, and patient-derived latent reservoir virus (Tuyishime et al., submitted) will likely help identify optimal combinations of DART molecules.

At present, blinatumomab, a CD19 × CD3 antibody-based bispecific molecule, is the only example of an immune cellengaging bispecific drug that has FDA approval for the treatment of disease-B cell acute lymphoblastic leukemia (69, 70). However, there are dozens of bispecific antibody-based molecules in various stages of development, and clinical testing, against multiple types of cancers $(71,72)$. This includes several DART molecules being evaluated for potential use in treatment of leukemias and lymphomas $(73,74)$, colorectal cancer (55), and solid tumors (75). The majority of bispecifics in development are intended to recruit $\mathrm{T}$ cells via an anti-CD3 arm, however NK cell recruitment by anti-CD16 targeting is also being explored $(76,77)$. The continued development and clinical testing of DART molecules, and other antibody-based bispecifics, for use against human cancers will provide important safety, durability, and efficacy data that will help inform the best strategies for use of these types of therapies against other diseases, including HIV-1 infection.

In summary, we demonstrated that HIV $\times$ CD3 and HIV $\times$ CD16 DART molecules can recruit and redirect cytolytic immune cells present in cord blood to eliminate autologous $\mathrm{T}$ cells infected with HIV-1, albeit less effectively than cells present in adult peripheral blood. Our work supports the continued development of these antibody-based molecules as components of passive immunization strategies aimed at treatment and cure of pediatric HIV. However, future studies using early life blood and tissue samples, and infant or juvenile preclinical animal models, will be required to identify tenable strategies to optimize their efficacy.

\section{DATA AVAILABILITY STATEMENT}

The datasets generated for this study are available on request to the corresponding author.

\section{REFERENCES}

1. Nduati R, John G, Mbori-Ngacha D, Richardson B, Overbaugh J, Mwatha A, et al. Effect of breastfeeding and formula feeding on transmission of HIV-1: a randomized clinical trial. JAMA. (2000) 283:1167-74. doi: 10.1001/jama.283. 9.1167

2. Chasela CS, Hudgens MG, Jamieson DJ, Kayira D, Hosseinipour MC, Kourtis AP, et al. Maternal or infant antiretroviral drugs to reduce HIV-1

\section{ETHICS STATEMENT}

Anonymized human umbilical cord blood donations that failed to meet the criteria required for clinical use were obtained with informed written consent. Human peripheral venous blood was collected by leukapheresis from healthy consenting adult volunteers $(28,29)$. All samples were collected in accordance with the policies and regulations of the Duke Health Institutional Review Board.

\section{AUTHOR CONTRIBUTIONS}

JP conceived the study, performed experiments, analyzed and interpreted data, and wrote the manuscript. RE performed experiments and analyzed data. SJ performed statistical analyses. $\mathrm{TH}$ and JAP performed experiments and analyzed data. C-YL, LL, GD, and JN led the design, development, and production of the bispecific dart molecules. SP isolated and characterized the breast milk transmitted/founder HIV-1 virus. TD collected and characterized the adult leukapheresis samples. SP and GF interpreted data and contributed to design of the study. All authors commented on the manuscript and approved the final version.

\section{FUNDING}

This study was supported by a Susie Zeegen Award, from the Elizabeth Glaser Pediatric AIDS Foundation, a Derfner Foundation Pediatric Research Award from Duke Children's and the Children's Miracle Network Hospitals, National Institute of Allergy and Infectious Diseases (NIAID), National Institutes of Health (NIH) R21 AI127022, and NIH K01 OD024877, all to JP. This research was also supported by the Duke University Center for AIDS Research (CFAR), an $\mathrm{NIH}$ funded program (5P30 AI064518), the NIAID/NIH External Quality Assurance Program Oversight Laboratory (EQAPOL, HHSN272201000045C and HHSN272201700061C), National Institutes of Health CARE Grant 1UM1AI126619-01 and Contract no. HHSN272201500032C, and Collaboration for AIDS Vaccine Discovery (CAVD)/Comprehensive T Cell Vaccine Immune Monitoring Consortium (CTVIMC) grant from the Bill \& Melinda Gates Foundation (Grant ID\# OPP1032325).

\section{ACKNOWLEDGMENTS}

We thank Dr. Joanne Kurtzberg and the staff of the Carolinas Cord Blood Bank for assistance in acquiring human umbilical cord blood samples used for this study.

transmission. N Engl J Med. (2010) 362:2271-81. doi: 10.1056/NEJMoa 0911486

3. Tobin NH, Aldrovandi GM. Immunology of pediatric HIV infection. Immunol Rev. (2013) 254:143-69. doi: 10.1111/imr.12074

4. UNAIDS. Communities at the Centre - Global AIDS Update 2019. (2019) Geneva: WHO Library.

5. De Rossi A, Masiero S, Giaquinto C, Ruga E, Comar M, Giacca M, et al. Dynamics of viral replication in infants with vertically acquired human 
immunodeficiency virus type 1 infection. J Clin Invest. (1996) 97:323-30. doi: 10.1172/JCI118419

6. Rouzioux C, Burgard M, Chaix ML, Delamare C, Cirau N, Bouiller $B$, et al. Human immunodeficiency virus-1 infection in neonates: correlation of plasma and cellular viremia and clinical outcome. French pediatric cohort study group. Acta Paediatr Suppl. (1997) 421:17-21. doi: 10.1111/j.1651-2227.1997.tb18314.x

7. Shearer WT, Quinn TC, Larussa P, Lew JF, Mofenson L, Almy $S$, et al. Viral load and disease progression in infants infected with human immunodeficiency virus type 1 . Women and infants transmission study group. $N$ Engl J Med. (1997) 336:1337-42. doi: 10.1056/NEJM199705083361901

8. Abrams EJ, Weedon J, Steketee RW, Lambert G, Bamji M, Brown T, et al. Association of human immunodeficiency virus (HIV) load early in life with disease progression among HIV-infected infants. New York city perinatal HIV transmission collaborative study group. J Infect Dis. (1998) 178:101-8. doi: 10.1086/515596

9. Dickover RE, Dillon M, Leung KM, Krogstad P, Plaeger S, Kwok S, et al. Early prognostic indicators in primary perinatal human immunodeficiency virus type 1 infection: importance of viral RNA and the timing of transmission on long-term outcome. J Infect Dis. (1998) 178:375-87. doi: 10.1086/515637

10. Palumbo PE, Raskino C, Fiscus S, Pahwa S, Fowler MG, Spector SA, et al. Predictive value of quantitative plasma HIV RNA and CD4+ lymphocyte count in HIV-infected infants and children. JAMA. (1998) 279:756-61. doi: 10.1001/jama.279.10.756

11. Rich KC, Fowler MG, Mofenson LM, Abboud R, Pitt J, Diaz C, et al. Maternal and infant factors predicting disease progression in human immunodeficiency virus type 1-infected infants. Women and infants transmission study group. Pediatrics. (2000) 105:e8. doi: 10.1542/peds.105.1.e8

12. Richardson BA, Mbori-Ngacha D, Lavreys L, John-Stewart GC, Nduati R, Panteleeff DD, et al. Comparison of human immunodeficiency virus type 1 viral loads in Kenyan women, men, and infants during primary and early infection. J Virol. (2003) 77:7120-3. doi: 10.1128/JVI.77.12.7120-7123.2003

13. Persaud D, Gay H, Ziemniak C, Chen YH, Piatak M Jr, Chun TW, et al. Absence of detectable HIV-1 viremia after treatment cessation in an infant. N Engl J Med. (2013) 369:1828-35. doi: 10.1056/NEJMoa1302976

14. Luzuriaga K, Gay H, Ziemniak C, Sanborn KB, Somasundaran M, RainwaterLovett $\mathrm{K}$, et al. Viremic relapse after HIV-1 remission in a perinatally infected child. N Engl J Med. (2015) 372:786-8. doi: 10.1056/NEJMc1413931

15. Richman DD. HIV: cure by killing. Nature. (2015) 528:198-9. doi: $10.1038 /$ nature 16321

16. Ferrari G, Haynes BF, Koenig S, Nordstrom JL, Margolis DM, Tomaras GD, et al. Envelope-specific antibodies and antibody-derived molecules for treating and curing HIV infection. Nat Rev Drug Discov. (2016) 15:823-34. doi: $10.1038 / \mathrm{nrd} .2016 .173$

17. Sloan DD, Lam CY, Irrinki A, Liu L, Tsai A, Pace CS, et al. Targeting HIV reservoir in infected CD4 $\mathrm{T}$ cells by dual-affinity re-targeting molecules (DARTs) that bind HIV envelope and recruit cytotoxic T cells. PLoS Pathog. (2015) 11:e1005233. doi: 10.1371/journal.ppat.1005233

18. Sung JA, Pickeral J, Liu L, Stanfield-Oakley SA, Lam CY, Garrido C, et al. Dual-affinity re-targeting proteins direct $\mathrm{T}$ cell-mediated cytolysis of latently HIV-infected cells. J Clin Invest. (2015) 125:4077-90. doi: 10.1172/JCI82314

19. Moore PA, Zhang W, Rainey GJ, Burke S, Li H, Huang L, et al. Application of dual affinity retargeting molecules to achieve optimal redirected T-cell killing of B-cell lymphoma. Blood. (2011) 117:4542-51. doi: 10.1182/blood-2010-09-306449

20. Shan L, Deng K, Shroff NS, Durand CM, Rabi SA, Yang HC, et al. Stimulation of HIV-1-specific cytolytic T lymphocytes facilitates elimination of latent viral reservoir after virus reactivation. Immunity. (2012) 36:491-501. doi: 10.1016/j.immuni.2012.01.014

21. Deng K, Pertea M, Rongvaux A, Wang L, Durand CM, Ghiaur G, et al. Broad CTL response is required to clear latent HIV-1 due to dominance of escape mutations. Nature. (2015) 517:381-5. doi: 10.1038/ nature 14053

22. Strain MC, Little SJ, Daar ES, Havlir DV, Gunthard HF, Lam RY, et al. Effect of treatment, during primary infection, on establishment and clearance of cellular reservoirs of HIV-1. J Infect Dis. (2005) 191:1410-8. doi: 10.1086/ 428777
23. Chun TW, Nickle DC, Justement JS, Meyers JH, Roby G, Hallahan CW, et al. Persistence of HIV in gut-associated lymphoid tissue despite longterm antiretroviral therapy. J Infect Dis. (2008) 197:714-20. doi: 10.1086/ 527324

24. Boasso A, Shearer GM, Chougnet C. Immune dysregulation in human immunodeficiency virus infection: know it, fix it, prevent it?. J Intern Med. (2009) 265:78-96. doi: 10.1111/j.1365-2796.2008. 02043.x

25. Martinez-Bonet M, Puertas MC, Fortuny C, Ouchi D, Mellado MJ, Rojo P, et al. Establishment and replenishment of the viral reservoir in perinatally HIV-1-infected children initiating very early antiretroviral therapy. Clin Infect Dis. (2015) 61:1169-78. doi: 10.1093/cid/ civ456

26. Strauss-Albee DM, Liang EC, Ranganath T, Aziz N, Blish CA. The newborn human NK cell repertoire is phenotypically formed but functionally reduced. Cytometry B Clin Cytom. (2017) 92:33-41. doi: 10.1002/cyto.b.21485

27. Fike AJ, Kumova OK, Carey AJ. Dissecting the defects in the neonatal CD8(+) T-cell response. J Leukoc Biol. (2019) 106:1051-61. doi: 10.1002/JLB.5RU0319-105R

28. Garcia A, Keinonen S, Sanchez AM, Ferrari G, Denny TN, Moody MA. Leukopak PBMC sample processing for preparing quality control material to support proficiency testing programs. J Immunol Methods. (2014) 409:99-106. doi: 10.1016/j.jim.2014.05.019

29. Sambor A, Garcia A, Berrong M, Pickeral J, Brown S, Rountree W, et al. Establishment and maintenance of a PBMC repository for functional cellular studies in support of clinical vaccine trials. J Immunol Methods. (2014) 409:107-16. doi: 10.1016/j.jim.2014.04.005

30. Johnson S, Burke S, Huang L, Gorlatov S, Li H, Wang W, et al. Effector cell recruitment with novel Fv-based dual-affinity re-targeting protein leads to potent tumor cytolysis and in vivo B-cell depletion. J Mol Biol. (2010) 399:436-49. doi: 10.1016/j.jmb.2010.04.001

31. Graves AJ, Padilla MG, Hokey DA. OMIP-022: comprehensive assessment of antigen-specific human T-cell functionality and memory. Cytometry A. (2014) 85:576-9. doi: 10.1002/cyto.a.22478

32. Fisher L, Zinter M, Stanfield-Oakley S, Carpp LN, Edwards RW, Denny T, et al. Vaccine-induced antibodies mediate higher antibody-dependent cellular cytotoxicity after interleukin-15 pretreatment of natural killer effector cells. Front Immunol. (2019) 10:2741. doi: 10.3389/fimmu.2019.02741

33. Eller MA, Currier JR. OMIP-007: phenotypic analysis of human natural killer cells. Cytometry A. (2012) 81:447-9. doi: 10.1002/cyto.a.22033

34. Fouda GG, Mahlokozera T, Salazar-Gonzalez JF, Salazar MG, Learn G, Kumar SB, et al. Postnatally-transmitted HIV-1 envelope variants have similar neutralization-sensitivity and function to that of non-transmitted breast milk variants. Retrovirology. (2013) 10:3. doi: 10.1186/1742-4690-10-3

35. Edmonds TG, Ding H, Yuan X, Wei Q, Smith KS, Conway JA, et al. Replication competent molecular clones of HIV-1 expressing Renilla luciferase facilitate the analysis of antibody inhibition in PBMC. Virology. (2010) 408:1-13. doi: 10.1016/j.virol.2010. 08.028

36. O'doherty U, Swiggard WJ, Malim MH. Human immunodeficiency virus type 1 spinoculation enhances infection through virus binding. J Virol. (2000) 74:10074-80. doi: 10.1128/JVI.74.21.10074-10080.2000

37. Lewis GK. Qualitative and quantitative variables that affect the potency of $\mathrm{Fc}$ - mediated effector function in vitro and in vivo: considerations for passive immunization using non-neutralizing antibodies. Curr HIV Res. (2013) 11:354-64. doi: 10.2174/1570162X1131166 60060

38. Betts MR, Brenchley JM, Price DA, De Rosa SC, Douek DC, Roederer M, et al Sensitive and viable identification of antigen-specific CD8 $+\mathrm{T}$ cells by a flow cytometric assay for degranulation. J Immunol Methods. (2003) 281:65-78. doi: 10.1016/S0022-1759(03)00265-5

39. D'arena G, Musto P, Cascavilla N, Di Giorgio G, Fusilli S, Zendoli F, et al. Flow cytometric characterization of human umbilical cord blood lymphocytes: immunophenotypic features. Haematologica. (1998) 83:197-203.

40. Thome JJ, Bickham KL, Ohmura Y, Kubota M, Matsuoka N, Gordon C, et al. Early-life compartmentalization of human $\mathrm{T}$ cell differentiation and regulatory function in mucosal and lymphoid tissues. Nat Med. (2016) 22:727. doi: $10.1038 / \mathrm{nm} .4008$ 
41. Mccarron MJ, Reen DJ. Neonatal CD8+ T-cell differentiation is dependent on interleukin-12. Hum Immunol. (2010) 71:1172-9. doi: 10.1016/j.humimm.2010. 09.004

42. Chen L, Flies DB. Molecular mechanisms of $\mathrm{T}$ cell co-stimulation and co-inhibition. Nat Rev Immunol. (2013) 13:227-42. doi: 10.1038/ nri3405

43. Moore PL, Crooks ET, Porter L, Zhu P, Cayanan CS, Grise H, et al. Nature of nonfunctional envelope proteins on the surface of human immunodeficiency virus type 1. J Virol. (2006) 80:2515-28. doi: 10.1128/JVI.80.5.2515-25 28.2006

44. Carson WE, Giri JG, Lindemann MJ, Linett ML, Ahdieh M, Paxton R, et al. Interleukin (IL) 15 is a novel cytokine that activates human natural killer cells via components of the IL-2 receptor. J Exp Med. (1994) 180:1395-403. doi: 10.1084/jem.180. 4.1395

45. Dalle JH, Menezes J, Wagner E, Blagdon M, Champagne J, Champagne MA, et al. Characterization of cord blood natural killer cells: implications for transplantation and neonatal infections. Pediatr Res. (2005) 57:649-55. doi: 10.1203/01.PDR.0000156501.5 5431.20

46. Garrido C, Abad-Fernandez M, Tuyishime M, Pollara JJ, Ferrari G, SorianoSarabia N, et al. Interleukin-15-stimulated natural killer cells clear HIV-1infected cells following latency reversal ex vivo. J Virol. (2018) 92:e00235-18. doi: 10.1128/JVI.00235-18

47. Ferrari G, Pollara J, Tomaras GD, Haynes BF. Humoral and innate antiviral immunity as tools to clear persistent HIV infection. J Infect Dis. (2017) 215:S152-9. doi: 10.1093/infdis/jiw555

48. Kim Y, Anderson JL, Lewin SR. Getting the "kill" into "shock and kill:" strategies to eliminate latent HIV. Cell Host Microbe. (2018) 23:14-26. doi: 10.1016/j.chom.2017.12.004

49. Rainwater-Lovett K, Luzuriaga K, Persaud D. Very early combination antiretroviral therapy in infants: prospects for cure. Curr Opin HIV AIDS. (2015) 10:4-11. doi: 10.1097/COH.0000000000 000127

50. Luzuriaga K. Early combination antiretroviral therapy limits HIV-1 persistence in children. Annu Rev Med. (2016) 67:201-13. doi: 10.1146/annurev-med-091114-1 11159

51. Sandritter T. Palivizumab for respiratory syncytial virus prophylaxis. J Pediatr Health Care. (1999) 13:191-5. doi: 10.1016/S0891-5245(99) 90039-1

52. Hermann E, Truyens C, Alonso-Vega C, Even J, Rodriguez P, Berthe A, et al. Human fetuses are able to mount an adultlike CD8 Tcell response. Blood. (2002) 100:2153-8. doi: 10.1182/blood.V100. 6.2153

53. Marchant A, Appay V, Van Der Sande M, Dulphy N, Liesnard C, Kidd $\mathrm{M}$, et al. Mature $\mathrm{CD} 8(+) \mathrm{T}$ lymphocyte response to viral infection during fetal life. J Clin Invest. (2003) 111:1747-55. doi: 10.1172/JCI200 317470

54. Dauby N, Goetghebuer T, Kollmann TR, Levy J, Marchant A. Uninfected but not unaffected: chronic maternal infections during pregnancy, fetal immunity, and susceptibility to postnatal infections. Lancet Infect Dis. (2012) 12:330-40. doi: 10.1016/S1473-3099(11) 70341-3

55. Moore PA, Shah K, Yang Y, Alderson R, Roberts $\mathrm{P}$, Long V, et al. Development of MGD007, a gpA33 x CD3-bispecific DART protein for Tcell immunotherapy of metastatic colorectal cancer. Mol Cancer Ther. (2018) 17:1761-72. doi: 10.1158/1535-7163.MCT-17-1086

56. Sandberg JK, Fast NM, Jordan KA, Furlan SN, Barbour JD, Fennelly G, et al. HIV-specific CD8+ T cell function in children with vertically acquired HIV-1 infection is critically influenced by age and the state of the CD4+ T cell compartment. J Immunol. (2003) 170:4403-10. doi: 10.4049/jimmunol.17 0.8.4403

57. Chen SF, Tu WW, Sharp MA, Tongson EC, He XS, Greenberg HB, et al. Antiviral CD8 T cells in the control of primary human cytomegalovirus infection in early childhood. J Infect Dis. (2004) 189:1619-27. doi: 10.1086/ 383249
58. Pitcher CJ, Hagen SI, Walker JM, Lum R, Mitchell BL, Maino VC, et al. Development and homeostasis of T cell memory in rhesus macaque. $J$ Immunol. (2002) 168:29-43. doi: 10.4049/jimmunol.168.1.29

59. Verneris MR, Miller JS. The phenotypic and functional characteristics of umbilical cord blood and peripheral blood natural killer cells. Br J Haematol. (2009) 147:185-91. doi: 10.1111/j.1365-2141.2009.07768.x

60. Liu D, Bryceson YT, Meckel T, Vasiliver-Shamis G, Dustin ML, Long EO. Integrin-dependent organization and bidirectional vesicular traffic at cytotoxic immune synapses. Immunity. (2009) 31:99-109. doi: 10.1016/j.immuni.2009.05.009

61. Lin SJ, Yan DC. ICAM-1 (CD54) expression on T lymphocytes and natural killer cells from umbilical cord blood: regulation with interleukin12 and interleukin-15. Cytokines Cell Mol Ther. (2000) 6:161-4. doi: $10.1080 / \mathrm{mccm} \cdot 6.4 \cdot 161.164$

62. Wang $\mathrm{Y}, \mathrm{Xu} \mathrm{H}$, Zheng $\mathrm{X}$, Wei $\mathrm{H}$, Sun $\mathrm{R}$, Tian Z. High expression of NKG2A/CD94 and low expression of granzyme $B$ are associated with reduced cord blood NK cell activity. Cell Mol Immunol. (2007) 4:377-82.

63. Stacey AR, Norris PJ, Qin L, Haygreen EA, Taylor E, Heitman J, et al. Induction of a striking systemic cytokine cascade prior to peak viremia in acute human immunodeficiency virus type 1 infection, in contrast to more modest and delayed responses in acute hepatitis B and C virus infections. J Virol. (2009) 83:3719-33. doi: 10.1128/JVI.0 1844-08

64. Qian JX, Lee SM, Suen Y, Knoppel E, Van De Ven C, Cairo MS. Decreased interleukin-15 from activated cord versus adult peripheral blood mononuclear cells and the effect of interleukin-15 in upregulating antitumor immune activity and cytokine production in cord blood. Blood. (1997) 90:3106-17. doi: 10.1182/blood.V90.8.3106

65. Xu W, Jones M, Liu B, Zhu X, Johnson CB, Edwards AC, et al. Efficacy and mechanism-of-action of a novel superagonist interleukin15: interleukin-15 receptor $\alpha \mathrm{Su} / \mathrm{Fc}$ fusion complex in syngeneic murine models of multiple myeloma. Cancer Res. (2013) 73:3075-86. doi: 10.1158/0008-5472.CAN-12-2357

66. Thaysen-Andersen M, Chertova E, Bergamaschi C, Moh ES, Chertov O, Roser J, et al. Recombinant human heterodimeric IL-15 complex displays extensive and reproducible N- and O-linked glycosylation. Glycoconj J. (2016) 33:417-33. doi: 10.1007/s10719-015-9627-1

67. Alsahafi N, Bakouche N, Kazemi M, Richard J, Ding S, Bhattacharyya S, et al. An asymmetric opening of HIV-1 envelope mediates antibodydependent cellular cytotoxicity. Cell Host Microbe. (2019) 25:578 e575. doi: $10.1016 /$ j.chom.2019.03.002

68. Lu M, Ma X, Castillo-Menendez LR, Gorman J, Alsahafi N, Ermel $\mathrm{U}$, et al. Associating HIV-1 envelope glycoprotein structures with states on the virus observed by smFRET. Nature. (2019) 568:415-9. doi: 10.1038/s41586-019-1101-y

69. Nagorsen D, Kufer P, Baeuerle PA, Bargou R. Blinatumomab: a historical perspective. Pharmacol Ther. (2012) 136:334-42. doi: 10.1016/j.pharmthera.2012.07.013

70. Przepiorka D, Ko CW, Deisseroth A, Yancey CL, Candau-Chacon R, Chiu HJ, et al. FDA approval: blinatumomab. Clin Cancer Res. (2015) 21:4035-9. doi: 10.1158/1078-0432.CCR-15-0612

71. Clynes RA, Desjarlais JR. Redirected T cell cytotoxicity in cancer therapy. Annu Rev Med. (2019) 70:437-50. doi: 10.1146/annurev-med-062617-035821

72. Suurs FV, Lub-De Hooge MN, De Vries EGE, De Groot DJA. A review of bispecific antibodies and antibody constructs in oncology and clinical challenges. Pharmacol Ther. (2019) 201:103-19. doi: 10.1016/j.pharmthera.2019.04.006

73. Chichili GR, Huang L, Li H, Burke S, He L, Tang Q, et al. XA CD3xCD123 bispecific DART for redirecting host $\mathrm{T}$ cells to myelogenous leukemia: preclinical activity and safety in non-human primates. Sci. Transl. Med. Blinatumoma 7:289ra282. doi: 10.1126/scitranslmed.aaa5693

74. Liu L, Lam CK, Long V, Widjaja L, Yang Y, Li H, et al. MGD011, A CD19 $\mathrm{x} C \mathrm{CD} 3$ dual-affinity retargeting bi-specific molecule incorporating extended circulating half-life for the treatment of B-cell malignancies. Clin Cancer Res. (2017) 23:1506-18. doi: 10.1158/1078-0432.CCR-16-0666

75. Spira A, Goldberg S, Strauss J, Bendell J, Cote G, Rahma E, et al. A phase 1 , open label, dose escalation study of MGD009, a B7-H3 x CD3 DART ${ }^{\circledR}$ 
protein, in combination with MGA012, an anti-PD-1 antibody, in patients with relapsed or refractory B7-H3-expressing tumors. J Immuno Ther Cancer. (2018) 6:P305. doi: 10.1200/JCO.2018.36.15_suppl.TPS2601

76. Rothe A, Sasse S, Topp MS, Eichenauer DA, Hummel H, Reiners KS, et al. A phase 1 study of the bispecific anti-CD30/CD16A antibody construct AFM13 in patients with relapsed or refractory Hodgkin lymphoma. Blood. (2015) 125:4024-31. doi: 10.1182/blood-2014-1 $2-614636$

77. Vallera DA, Felices M, Mcelmurry R, Mccullar V, Zhou X, Schmohl JU, et al. IL15 trispecific killer engagers (TriKE) make natural killer cells specific to $\mathrm{CD} 33+$ targets while also inducing persistence, in vivo expansion, and enhanced function. Clin Cancer Res. (2016) 22:3440-50. doi: 10.1158/1078-0432.CCR-1 5-2710
Conflict of Interest: C-YL, LL, GD, and JN are employees of MacroGenics, Inc., and receive salaries and stock options as compensation for their employment.

The remaining authors declare that the research was conducted in the absence of any commercial or financial relationships that could be construed as a potential conflict of interest.

Copyright $\odot 2020$ Pollara, Edwards, Jha, Lam, Liu, Diedrich, Nordstrom, Huffman, Pickeral, Denny, Permar and Ferrari. This is an open-access article distributed under the terms of the Creative Commons Attribution License (CC BY). The use, distribution or reproduction in other forums is permitted, provided the original author(s) and the copyright owner(s) are credited and that the original publication in this journal is cited, in accordance with accepted academic practice. No use, distribution or reproduction is permitted which does not comply with these terms. 